\title{
BACK TO THE FUTURE: \\ FROM CRITICAL LEGAL STUDIES \\ FORWARD TO LEGAL REALISM, OR \\ HOW NOT TO MISS THE POINT OF \\ THE INDETERMINACY ARGUMENT
}

\author{
JOHN HASNAS $\dagger$

\section{INTRODUCTION}

A woman living in a rural setting becomes ill and calls her family plysician, who is the only local doctor, for help. However, it is the doctor's day off and because he has a golf date, he does not respond. The woman's condition worsens, no other physician can be procured in time, and as a result, she dies. Her estate then sues the doctor for not coming to her aid. Legal research discovers a rule of law that holds that in the absence of an actual contract for services, there can be no liability. ${ }^{1}$ However, further research discovers another rule that holds that in the absence of an explicit contract, the law will imply a contractual relationship when sucl is necessary to avoid injustice. ${ }^{2}$ Which rule will the judge apply? If the judge believes that physicians are ordinary human beings who are entitled to lives of their own and are not required to be at the beck and call of their patients, he is likely to apply the rule that there is no liability in the absence of an exphicit con-

$\dagger$ J.D. \& Ph.D. Philosophy, Duke University, LL.M. Legal Education, Temple University, Assistant Professor of Business Ethics, Georgetown University, and Senior Research Fellow, Kennedy Institute of Ethics. The author wishes to thauk Madison Powers and William Blattner of Georgetown University; Richard Greenstein of Temple University School of Law; Loren Loniasky, Edward McClennen, Jim Child, Marvm Belzer, Christopher Morris, and Ellen Paul of Bowling Green State University; Charlotte Twight of Boise State University; Jennifer Roback of George Mason University; Raymond Belliotti of the State University of New York at Fredomia; Peter Boettke of New York University; and Ann C. Tunstall of the Weinberg Consulting Group for their exceedingly helpful comments. Thanks are also owed to Terrance Costello for his valuable research help and to Kory Swanson, Mary Dilsaver, and Tammi Sharp of the Social Philosophy and Policy Center for their assistance and support. An earlier version of this article was presented at the 1993 neeting of the Eastern Division of the American Philosophical Association.

1. See Hurley v. Eddingfield, 59 N.E. 1058 (Ind. 1901).

2. See Cotnam v. Wisdom, 104 S.W. 164 (Ark. 1907). 
tract. However, if the judge beheves that by entering the practice of medicine physicians take on a special obligation to care for the sick that it would be unjust to violate, he will be more likely to apply the rule implying a contractual relationship.

An auction house sells a painting for a bid of $\$ 100$. When the buyer has the painting appraised, it turns out to be a lost masterpiece worth millions. Upon learning of this, the auction house sues to rescind the contract of sale. Legal research discovers a rule of law that holds that a contract may be rescinded when there has been a mutual mistake concerning a material fact. ${ }^{3}$ If the contract was for the sale of an inexpensive painting, then there was clearly a mutual mistake. But if the contract was for the sale of a work of unknown value, there was not. How will the judge describe the object sold? If the judge behieves that the purpose of contract law is to ensure a fair bargain, he is likely to describe the object sold as an mexpensive painting and grant rescission. ${ }^{4}$ However, if the judge believes that the purpose of contract law is to encourage people to be self-reliant and careful in their dealings, he is likely to describe it as a work of unknown value and uphold the contract. $^{5}$

For the past three-quarters of a century, cases such as these have been used to argue that Anglo-American law is indeterminate; that the rules of law do not compel judges to decide cases one way rather than another. This "indeterinmacy argument," which was originally developed by the legal realists in tlie 1920 s and 30s, was famously revived and updated in the 1980s by the adlierents of the Critical Legal Studies movement (heremafter "Crits") to serve as the spearhead of their crusade against legal liberalism. The Crits employed this argument to claim that the liberal concept of the rule of law was a myth designed to maintain the illegitimate domination of society by the economically and politically powerful. ${ }^{6}$ This contention touched off a decade-long jurisprudential wrangle between the Crits and more traditional legal scholars regarding the nature and extent of legal indeterminacy. Througliout the 1980s and early 1990s, so much ink was spil-

3. See, e.g., Sherwood v. Walker, 33 N.W. 919 (Mich. 1887); Wood v. Boynton, 25 N.W. 42 (Wis. 1885).

4. See Sherwood, 33 N.W. at 919.

5. See Wood, 25 N.W. at 42.

6. See infra notes $51-55$ and accompanying text. 
led on this topic that today-only eighteen years after the First Conference on Critical Legal Studies-the dispute over the indeterminacy argument, and to some extent, the Crits themselves, are regarded as passé.

I think this is unfortunate because I beheve that in the midst of the struggle over the cogency of the indeterminacy argument, the implications it holds for our future jurisprudential endeavors have been overlooked. Accordingly, I would like to revisit the subject, not to reprise the debate over whether the indeterminacy argument is in fact correct, but to examine what follows froin the assumption that it is. In this article, I argue that the use the Crits make of the indeterminacy argument suggests that they have missed its essential point. I also contend that the indeterminacy argument recommends not the radical pohitical action advocated by the Crits, but rather the thoroughly pragmatic approach to the law urged by the realists over half a century ago. Thus, I suggest that, correctly understood, the indeterminacy argument leads us not in the direction the Crits would take us, but back to the unfinished project of the legal realists. I further suggest that the public choice scholars represent a group of theorists who are currently pursuing this project, and thus that it is they, rather than the Crits, who are truly following the line of analysis the indeterminacy argument recommends. Finally, I suggest that given the knowledge that these scholars and earlier classical hiberal economists have developed, the indeterminacy argument may afford as much support to the classical liberal agenda as it does to the Critical one.

\section{A BRIEF HISTORY OF THE INDETERMINACY ARGUMENT}

The indeterminacy argument was origmally developed by the legal realists ${ }^{7}$ as a critique of the legal formalism of the late nineteenth and early twentieth centuries. ${ }^{8}$ During this era of "classical

7. The realists were an exceptionally diverse group of legal scholars whose work stretched from the 1920 s through the 1950 s. It may be that they are only identifiable as a school of jurisprudential thought because of Karl Llewellyn's catalogue of scholars whose work shared nine common features in his 1931 article, Some Realism About Realism-Responding to Dean Pound, 44 HARV. L. REV. 1222, 1226-28 n.18 (1931). For this reason, generalizations that attempt to describe what "the realists" thought are problematic. However, brevity requires such generalizations. Thus, for purposes of this article, references to "the realists" should be read as applying only to those scholars actually cited in the notes.

8. See Gary Minda, The Jurisprudential Movements of the 1980s, 50 OHIO ST. L.J. 
legal consciousness," judicial decisionmaking was viewed as "a scientific, deductive process by which preexisting legal materials subsume particular legal cases under their domain, thus allowing judges to infer the antecedently existing right answer to the case at bar." ${ }^{110}$ This formalistic approach viewed the judge as one who objectively and impersonally decides cases by logically deducing the correct resolution from a definite and consistent body of legal rules. ${ }^{11}$ Thus, the judge did not make law; he merely apphed the law that had been created by the legislature or was inherent in the common law. ${ }^{12}$

599, 633-34 (1989); Note, 'Round and 'Round the Bramble Bush: From Legal Realism to Critical Legal Studies, 95 HARV. L. REv. 1669, 1670 (1982).

9. See Elizabeth Mensch, The History of Mainstream Legal Thought, in THE POLITICS OF LAW: A PROGRESSIVE CRITIQUE 13, 18 (David Kairys ed., rev. ed. 1990) [hereinafter THE POLITICS OF LAW]; Duncan Kennedy, Toward an Historical Understanding of Legal Consciousness: The Case of Classical Legal Thought in America 1850-1940, in 3 RES. L. \& SOC. 3 (Rita J. Simon \& Steven Spitzer eds., 1980); Joseph W. Singer, Legal Realism Now, 76 CAL. L. REV. 465 (1988).

10. RAYMOND A. BELLIOTTI, JUSTIFYING LAW 4 (1992).

11. See Karl N. Llewellyn, The Common law Tradition: Deciding appeals 24-25 (1960). This deductive process has been most clearly described by Edward A. Purcell as follows:

That predominant legal theory claimed that reasoning proceeded syllogistically from rules and precedents that had been clearly defined historically and logically, through the particular facts of a case, to a clear decision. The function of the judge was to discover analytically the proper rules and precedents involved and to apply them to the case as first premises. Once he had done that, the judge could decide the case with certainty and uniformity.

Edward A. PURCELI, JR., THE CRISIS OF Democratic TheORY 74-75 (1973). It should be noted that actual adherents of legal formalism have been notoriously difficult to locate. John M. Zane appears to be the usual suspect because he wrote:

Every judicial act resulting in a judgment consists of a pure deduction. The figure of its reasoning is the stating of a rule applicable to certain facts, a finding that the facts of the particular case are those certain facts and the application of the rule is a logical necessity. The old syllogism, "All men are mortal, Socrates is a man, therefore he is mortal", states the exact form of a judicial judgment. The existing rule of law is: Every inan who with malice aforethought kills another in the peace of the people is guilty of murder. The defendant with malice aforethought killed A.B. in the peace of the people, therefore the defendant is guilty of murder.

John M. Zane, German Legal Philosophy, 16 MiCH. L. REv. 287, 338 (1918). See also Charles W. Bacon \& Franklyn S. Morse, The Reasonableness of the law: The ADAPTABILITY OF LEgAL SANCTIONS TO THE NEEDS OF SOCIETY (1924) (arguing that law is the perfection of reason).

12. See Richard M. Fischl, Some Realism About Critical Legal Studies, 41 U. MIAMI L. Rev, 505, 511 (1987); Mensch, supra note 9, at 19; Singer supra note 9, at 496-97. Legal formalism has also been referred to as mechanical jurisprudence, see Roscoe Pound, Mechanical Jurisprudence, 8 Colum. L. REv. 605 (1908); Minda, supra note 8, conceptualism, see Allan C. Hutchinson \& Patrick J. Monahan, Law, Politics, and the 
The realists introduced the indeterminacy argument to demonstrate that the application of the principles of deductive reasoning to the set of legal materials did not and could not uniquely determine the outcome of particular cases; that judicial decisions were not "rationally deducible from a closed system of law." gument was based on two observations. The first was that the law is riddled with contradictory rules such that a judge will always have a cloice between "competing rules leading to opposing outcomes." 14 My initial hypothetical concerning the physician who does not respond to the call of a regular patient was designed to illustrate this observation. The second was that it is always possible for a judge to interpret the breadth of the rules and the facts

Critical Legal Scholars: The Unfolding Drama of American Legal Thought, 36 STAN. L. REv. 199 (1984); G. Edward White, The Inevitability of Critical Legal Studies, 36 STAN. L. REV. 649 (1984), and scientific jurisprudence, see Fischl, supra, at 511.

13. Richard K. Greeustein, The Nature of Legal Argument: The Personal Jurisdiction Paradigm, 38 HASTINGS L.J. 855, 884 (1987). Most of the realists were social reformers who were reacting against the decisions of the Suprene Court during the so-called Lochner era in which the Court routinely struck down social welfare legislation as being inconsistent with the liberty of contract. See, e.g., Lochner v. New York, 198 U.S. 45 (1905) (invahdating a New York statute restricting bakers' working hours to 10 hours per day); Coppage v. Kansas, 236 U.S. 1 (1915) (invalidating Kansas statute prohibiting "yellow dog" contracts). For this reason, the indeterminacy argument is usually seen as having been developed to combat this strain of hbertarian Supreme Court jurisprudence. See Mensch, supra note 9, at 18-21; Singer, supra note 9, at 477 ("A major goal of the legal realists was to undermine laissez-faire ideology by attacking the idea of a self-regulating market system based on free contract ... ."); Hutchinson \& Monahan, supra note 12, at 203-04. However, although this is certainly responsible for much of the attention paid to the argument, the argument itself clearly predates these decisions since it was given its prototypical expression as early as 1897 by Oliver Wendell Holmes:

The language of judicial decision is mainly the language of logic. And the logical method and form flatter that longing for certainty and for repose which is in every human mind. But certainty generally is illusion, and repose is not the destiny of man. Behind the logical form lies a judgment as to the relative worth and importance of competing legislative grounds, often an marticulate and unconscious judgment, it is true, and yet the very root and nerve of the whole proceeding. You can give any conclusion a logical form.

Oliver Wendell Holmes, The Path of the Law, 10 HARV. L. REv. 457, $465-66$ (1897).

14. Andrew Altınan, Legal Realism, Critical Legal Studies, and Dworkin, 15 PHIL. \& PUB. AFF. 205, 209 (1986) (citing Karl N. Llewellyn, Some Realism About Realism, 44 HARV. L. REV. 1222, 1252 (1931)); Singer, supra note 9, at 470; see also FELIX S. CoHEN, The Problems of a Functional Jurisprudence, in THE LEGAL CONSCIENCE 77, 83 (Lucy Kramer Cohen ed., 1960) ("Legal principles have a liabit of running in pairs, a plaintiff principle and a defendant principle.") (citing Hessel E. Yntema, The Hornbook Method and the Conflict of Laws, 37 YALE L.J. 468 (1928)); Fischl, supra note 12, at 513 (describing realist argument that legal reasoning does not objectively require a particular result); Ken Kress, Legal Indeterminacy, 77 CAL. L. REv. 283, 297 (1989) (discussing KarL N. Llewellyn, The Bramble BuSh 66-69 (1951)). 
of the case so as to generate conflicting results. This is because the rules are expressed in such vague language (e.g., "reasonable," "due process," "fair value," etc.) as to allow thein to be read as broadly or as narrowly as necessary to achieve any desired result, ${ }^{15}$ and because it is the judges themselves who characterize the facts of the case and decide which are relevant. ${ }^{16}$ My hypothetical involving the painting sold at auction was designed to illustrate this observation.

The purpose of the indeterminacy argunent was to demonstrate that the formalist image of the judge as one who does not make law, but impersonally discovers and applies antecedently existing law, was a mytl. It imphed that the rules of law could not constrain judges' choices since it was the judges who chose which rules to apply and low to apply them. Further, since such choices were necessarily based on the judges' beliefs about what was right, it was the judges' personal value judgments that consciously or unconsciously formed the basis of their decisions.

For the realists, this had profound implications for both legal practice and legal theory. With regard to practice, the realists claimed that attorneys would be better able to predict the outcome of cases and correctly advise their clients if they studied the social factors that influenced judges' behavior rather than the syllogisms the judges offered in support of their decisions. ${ }^{17}$ With regard to theory, they beheved it deinanded a redirection of study away from the logical relationships among the abstract rules of

15. See Karl. N. Llewellyn, The Bramble Bush 56-69 (1960); Cohen, supra note 14, at 82-83; Walter W. Cook, The Logical and Legal Bases of the Conflict of Laws, 33 YALE L.J. 457, 467-68, 482 (1924); Max Radin, The Theory of Judicial Decision: Or How Judges Think, 11 A.B.A. J. 357, 361 (1925) ("If you are a little clever, [the rule] will catch or let out the situation you are deciding."); Singer, supra note 9, at 470. See also Altman, supra note 14, at 208 (noting that the realists recognize that within each group of rules which apply to any case there is a vagueness which could affect the case's outcome).

16. See JEROME FRANK, LAW AND THE MODERN MiND 106, 116 (1930); see also G. Edward White, From Sociological Jurisprudence to Realism: Jurisprudence and Social Change in Early Twentieth-Century America, 58 VA. L. REV. 999, 1018-19 (1972), reprinted in PATTERnS OF AMERICAN LEgal Thought 99, 123 (1978) (discussing FranK, supra, at 106).

17. See Jules L. Coleinan \& Brian Leiter, Determinacy, Objectivity, and Authority, 142 U. PA. L. REV. 549, 581 (1993). See generally FRANK, supra note 16, at 116; Joseph C. Hutcheson, Jr., The Judgment Intuitive: The Function of the "Hunch" in Judicial Decision, 14 CORNELl L.Q. 274, 277-88 (1929); Karl N. Llewellyn, A Realistic Jurisprudence-The Next Step, 30 Colum. L. REv. 431, 443 (1930). 
law and toward the actual effects of law and judicial decisionmaking on society. ${ }^{18}$

The reahists derided the resolution of legal cases through the manipulation of logical abstractions that took no account of social consequences as "word-magic"19 or "transcendental nonsense."20 By demonstrating that the purely formal processes of legal argumentation could not produce unique results, they believed they had shown that "[1]egal criticism is empty without objective description of the causes and consequences of legal decisions."21 Thus, they msisted on the "evaluation of any part of law in terms of its effects."22

18. See Felix S. Cohen, Ethical Systems ANd Legal Ideals 11-42 (1933); FRANK, supra note 16, at 121-32, 148-59, 264-84; Walter W. Cook, Scientific Method and the Law, 13 A.B.A. J. 303, 307-09 (1927); Llewellyn, supra note 17, at 447-48.

19. FRANK, supra note 16 , at $60,181$.

20. Felix S. Cohen, Transcendental Nonsense and the Functional Approach, 35 COLUM. L. REV. 809,812 (1935). The realists were quite imaginative in expressing derision for the formalistic legal method. For instance, Cohen considered legal propositions composed of "the magic 'solving words' of traditional jurisprudence" as "identical in metaphysical status with the question ... 'How many angels can stand on the point of a needle?" "Id. at 810 , and found that arguments based upon them "add precisely as much to our knowledge as Moliere's pliysician's discovery that opium puts men to sleep because it contains a dormative principle." Id. at 820 . Frank regarded such propositions as "virtually empty concepts [that] seem to give to the metaplysician the stable world he requires," FRANK, supra note 16, at 60 , while Underhill Moore called them "phantons drifting upon the stream of day dreams." Underhill Moore, Rational Basis of Legal Institutions, 23 COLUM. L. REv. 609, 612 (1923).

21. Cohen, supra note 20 , at 849 .

22. Llewellyn, supra note 7, at 1237. The need "to understand law in terms of its factual context and economic and social consequences," LAURA KALMAN, LEGAL REALISM AT YALE, 1927-1960, 3 (1986), was a consistent theme of the realist movennent. As early as 1897 , Oliver Wendell Holmes was waming that judges "have failed adequately to recognize their duty of weighing considerations of social advantage." Holmes, supra note 13, at 467. Karl Llewellyn charaeterized realistic jurisprudence as "a philosophy not only of Law, but also of Law's Function, and of Law's Operation, and of Legal Institutions: i.e., of Law and Law's Work, and Law's Personnel," Karl N. Llewellyn, On Reading and Using the Newer Jurisprudence, 40 COLUM. L. REv. 581, 606-07 (1940) (citations omitted), while Felix Cohen described it as aimed at "eliminating supernatural terms and meaningless questions and redefining concepts and problems in terms of verifiable realities. . . a as constructs, or functions, or complexes, or patterns, or arrangements, of the things that we do actually see or do." Cohen, supra note 20, at 822-26. One notablc example of this type of investigation was Underhill Moore and Cliarles Callalian's detailed study of the effects of parking and traffic regulations on the behavior of the inotorists of New Haven. Underhill Moore \&. Charles C. Callahan, Law and Learning Theory: A Study in Legal Control, 53 YALE L.J. 1 (1943).

To most of the realists, the call to evaluate the law "in terms of its effects" meant the application of the social sciences to the law. Llewellyn, supra note 7, at 1237 . Thus, Llewellyn declared that "[w]lien one approaches the law, not with the idea of formulating 
By the time West Coast Hotel Co. v. Parrish ${ }^{23}$ signalled the end of the Lochner era of Supreme Court jurisprudence in 1937, the indeterminacy argument had essentially carried the day against legal formahism. Lawyers now routinely presented "policy" arguments based on the social consequences of the decision in socalled "Brandeis briefs" 24 and, as exeinplified by Brown v. Board of Education, ${ }^{25}$ courts were increasingly willing to make such arguments the basis of their decisions. Despite this, there was great reluctance in the legal community to accept the full implications of legal indeterminacy. If the personal inotivations and values of judges rather than the rules of law determined the outcoine of cases, then, as the realists had pointed out, "[t]he ideal of a gov-

its rules into a system, but with an eye to discovering how much it does or can effect, . . economic theory offers in many respects amazing light." Karl N. Llewellyn, The Effect of Legal Institutions upon Economics, 15 AM. ECON. REV. 665, 682 (1925). Most realists were social reformers who beheved that the social sciences could provide the expertise required to employ the law as a method of social engineering to create a better world. See White, supra note 16 , at 124-25. Because administrative agencies were better equipped to provide such expertise than the judiciary, many reahists "advocated a power shift from the judiciary to expert state agencies." Raymond A. Belliotti, Is Law a Sham?, 48 PHIL. \& PHENOMENological REs. 25, 30 (1987). Several realists, such as Thurmon Aruold, Charles Clark, Felix Cohen, Walton H. Hamilton, Jerome Frank, Rexford G. Tugwell, and William O. Douglas, accepted public service posts in the New Deal to help carry out this project. See Note, supra note 8 , at 1675 n.41. This lime of thought culminated in the belief that it was possible to identify a scientifically determined conception of the pubhic interest that could be advanced by developing the proper legal policies. See Minda, supra note 8, at 635. Perhaps the most famous outgrowth of this was Harold Lasswell and Myres McDougal's attempt to reform legal education by employing the social sciences to consciously train future lawyers for policy-making. See Harold D. Lasswell \& Myres S. McDougal, Legal Education and Public Policy: Professional Training in the Public Interest, 52 YALE L.J. 203, 206 (1943). See generally PURCELL, supra note 11, at 74-94 (examining historical relationship between legal realism and the empiricism of the social sciences); Singer, supra note 9, at 468-75 (discussing the reahist emphasis on policy considerations and institutional concerns in legal education); White, supra note 16, at 122 (describing realist method of applying behavioral scientists' findings in adjudication).

The realist commitment to social science, administrative agencies, and policymaking has been subjected to much criticism. However, none of this is relevant for present purposes. In this article, I will be citing the realists only for their claim that the law should be evaluated on the basis of its actual effects on liuman beings and that therefore, study of its actual operation is required.

23. 300 U.S. 379 (1937).

24. This name came from the brief that Louis Brandeis submitted to the Supreme Court in Muller v. Oregon, 208 U.S. 412 (1908), which contained two pages of legal argument and over a liundred pages of sociological data and analysis. See PURCELL, supra note 11 , at 76 .

25. 347 U.S. 483 (1954). 
ernment of laws and not of men [was] a dream,"26 and there was no substantive difference between legal reasoning and political discourse. This seemed to deprive the law of its moral imprimatur and suggest that law was nothing more than the naked exercise of political power. Especially in the aftermath of World War II, this appeared to imply a dangerous form of relativism similar to that which had given rise to the authoritarian regimes the United States had just struggled to defeat. ${ }^{27}$ As a result, there was a felt need to distinguish the way the judiciary dealt with sociological data froin the purely political way in which the legislature did.

In the 1950s, this gave rise to the Legal Process school (usually associated with the materials developed by Henry Hart and Albert Sacks ${ }^{28}$ which cast the legislature and judiciary in distinctly different roles. Taking the value of democracy as their guiding force, the legal process theorists argued that it was the task of the democratically elected legislature to make substantive determinations of public policy. The courts, on the other hand, were restricted to deciding essentially procedural matters; they made determinations "not that a particular exercise of power was 'right' in any normative sense, but rather that the appropriate institution had used the procedures that made that institution appropriate for deciding the kind of issue it had decided."29 The process theorists

26. Hessel E. Yntema, The Hombook Method and the Conflict of Laws, 37 YALE L.J. 468,479 (1928).

27. See G. EDWARD WHITE, The Evolution of Reasoned Elaboration: Jurisprudential Criticism and Social Change, in PATTERNS OF AMERICAN LEgAL ThOught 136, 137-44 (1978); Mensch, supra note 9, at 23-24; Gary Peller, Neutral Principles in the 1950's, 21 U. MICH. J.L. REF. 561, 572-79 (1988).

28. See Henry M. Hart, JR. \& Albert M. Sacks, The legal Process: Basic PROBlemS IN THE MAKING AND APPLiCATION OF LAW (tent. ed. 1958). For a detailed account of the motivation for and development of legal process theory, see Peller, supra note 27. See also White, supra note 27.

29. Peller, supra note 27, at 570. According to legal process theory, courts were bound to act in accordance with the principle of institutional settlement. This principle held that since "[t]he alternative to disintegrating resort to violence is the establishment of regularized and peaceable methods of decision ... decisions which are the duly arrived at result of duly established procedures of this kind ought to be accepted as binding upon the whole society unless and until they are duly changed." HART \& SACKS, supra note 28 , at 4 . This implied that "an institutional decision was entitled to respect regardless of its substance, so long as the appropriate procedures for resolving a dispute had been observed," and thus, that "[o]nce such procedures were identified, it would be possible to assert neutrally the application of the normative prong of the "principle of institutional settlement,' the notion that a particular decision 'ought to be respected.'" Peller, supra note 27, at 593. 
believed that by thus restricting the realm of judicial decisionmaking, they could answer the reahists' challenge to the political neutrality of law since "[w] hile substantive decision making might ultimately be political, procedural analysis could be both normative and neutral."30 Thus, they believed that within this realm, judges could impersonally decide cases through the process of "reasoned elaboration," i.e., the elaboration of "principles and policies contained within precedent and legislation [that yielded] a reasoned, if not analytically determined, result in particular cases." ${ }^{31}$

An outgrowth of this commitment to judicial decision by reasoned elaboration was the call by Herbert Wechsler for neutral principles of constitutional interpretation. ${ }^{32}$ Wechsler freely admitted "what many for so long demied: that courts in constitutional determinations face issues that are inescapably 'pohtical' ... in that they involve a choice among competing values or desires.",33 However, he argued that since courts were "bound to function otherwise than as a naked power organ, ${ }^{, 34}$ they must make such determinations on the basis of "the type of reasoned explanation ... imtrinsic to judicial action,"35 i.e., on the basis of "reasons that in their generality and their neutrahty transcend any immediate result that is involved." ${ }^{36}$ Wechsler believed that if judges would decide cases strictly on the basis of sucl neutral principles ratlier than being result-driven, judicial decisionmaking could be rendered both determinate and politically neutral.

30. Peller, supra note 27 , at 590 .

31. Id. at 595 .

32. Herbert Weschler, Toward Neutral Principles of Constitutional Law, 73 HARV. L. REV. 1 (1959).

33. Id. at 15 .

34. Id. at 19.

35. Id. at $15-16$.

36. Id. at 19. Wechsler argued that what distinguished the judicial from the legislative method of rendering value judgments was that judicial decisionmaking was "principled." Id.

I put it to you that the main constituent of the judicial process is precisely that it must be genuinely principled, resting with respect to every step that is involved in reaching judgment on analysis and reasons quite transcending the immediate result that is achieved. To be sure, the courts decide, or should decide, only the case they have before them. But must they not decide on grounds of adequate neutrality and generality, tested not only by the instant apphication but by others that the principles imply?

Id. at 15. This argument foreshadowed the approach that Dworkin was to champion in the 1970s. See infra text accompanying note 41 . 
Meanwhile, more substantive challenges were being raised against the claim that the law is indeterminate. For example, H.L.A. Hart contended that the reahists had greatly exaggerated the anount of indeterminacy in the law. $\mathrm{He}$ argued that although there was indeed a "penumbra of doubt" of law did not yield determinate outcomes, there was also a much more extensive "core of certainty"38 within which they did. Hart attributed the indeterminacy that the realists had observed to the inherent "open texture" of legal rules which is "a general feature of human language," and argued that although this "uncertainty at the borderline is the price to be paid for the use of general classifying terms," both the rules of common law and legislation were definite enough to yield determinate results "over the great mass of ordinary cases." ${ }^{39}$ Thus, Hart saw legal indeterminacy as "a peripheral phenomenon in a system of rules which, by and large, does provide specific outcoines to cases." ${ }^{240}$

In the 1970s, Ronald Dworkm argued that even the amount of indeterminacy that Hart allowed was exaggerated. ${ }^{41}$ This was because Hart erroneously viewed the law as consisting exclusively in rules. Dworkin claimed that in addition to rules, the law was comprised of "principles, policies and other sorts of standards." In deciding cases, courts were called upon to construe not merely rules of law, but legal principles as well. ${ }^{43}$ In those cases in which the rules did not clearly decide the case, it was the principles that would "guide judges to a determinate outcoine." ${ }^{\text {"4 }}$ The judge's job was to render decisions that were rationally consistent with the

37. H.L.A. HART, THE CONCEPT OF LAW 119 (1961).

38. Id.

39. Id. at 124-25.

40. Altman, supra note 14 , at 207.

41. See RoNALD Dworkin, The Model of Rules I, in TAKINg RIGHTS SERIOUSLY 14 (1977).

42. Id. at 22. Policies are "standard[s] that set[] out a goal to be reached, generally an improvement in some economic, political, or social feature of the community." Id. In contrast, principles are "to be observed, not because it will advance or secure an economic, political, or social situation deemed desirable, but because it is a requirement of justice or fairness or some other dimension of morality." Id.

43. Although the legislature could consider both principles and policies in the lawmaking process, courts were restricted to the consideration of principles. RONALD DwoRKIN, Hard Cases, in TAKING RIGHTS SERIOUSLY, supra note 41, at 81, 84.

44. Altman, supra note 14 , at 212 . In this sense, Dworkin's argument is a natural outgrowth of Wechsler's earlier call for "principled" judicial decisionmaking. See supra note 36 and accompanying text. See also Altman, supra note 14, at 218 n.34. 
relevant set of legally authoritative rules and principles. ${ }^{45}$ Thus, Dworkin argued that by correctly identifying the "best" interpretation of these materials, judges were able to render determinate outcomes to legal controversies even in those cases in which appeal to the rules alone would provide ambiguous results. ${ }^{46}$

This set the stage for the remtroduction of the indeterminacy argument by the Crits. The legal commumity's response to realisin had been to recognize that the law consisted in principles, policies, and moral and pohtical ideals as well as rules, and to assert that within this enriched legal universe, proper attention to institutional competencies and roles as well as proper interpretive techniques could yield determinate outcomes. This response had allowed the legal community to absorb the realist insight that legal reasoning did not consist in the logical deduction of the outcome of cases from fixed, determinate rules while avoiding the more radical imphication that the law was imdistinguishable from poitics.

The Crits attacked this reconstruction of the legal systein by arguning that there was no sustainable distinction between process and substance and that the larger set of legally authoritative inaterials was itself mdeterminate. They claimed that the focus on procedures could never render judicial decisioninaking truly "neutral" since in order to determine that a legislative or administrative value determination was entitled to deference, "one had to make substantive political and ethical judgments about the permissible range and extent of institutional power. ${ }^{.47}$ They also claimed that

45. DWORKIN, supra note 43, at 105-23.

46. See, e.g., DWORKIN, supra note 41 ; DWORKIN, supra note 43.

47. Peller, supra note 27 , at 608 . Peller points out that the normative force of the claim that courts should respect the value determinations of the legislature (and administrative agencies) was derived from the commitment to democracy. However, this implied that a court could know that a legislative action should be respected only by first making the substantive normative determination that the legislature was in fact functioning democratically. Thus, process was not truly distinct from substance. He illustrated this with Herbert Wechsler's criticism of the decision in Brown v. Board of Education:

Finding that the issue in Brown involved a value judgment constituted merely half the analysis-before deference to the legislature was in order, the judiciary would have to decide that the legislature actually employed the procedures that made it competent to decide the issue, that is, that the legislature was truly democratic. . . . There was no neutral way to dccide the case on the basis of relative institutional processes because, in the identification of "democracy," process and substance overlapped. If the segregation of public schools was part of a state-supported institutionalized domination of blacks, the conclusion that the legislature was democratically legitimate was impugned unless deinocracy was consistent with such a widespread social domination that the concept lost its coherence as a legitimizer of social decision making. By advocating deference 
indeterminacy was not limited to the rules of law and could not be cured by appeal to legally authoritative principles. ${ }^{48}$ Rather, they argued that the realm of principles was itself comprised of contradictory principles and ideals and that there were no metaprinciples available for resolving these contradictions. ${ }^{49}$ To the Crits, the "invocation of principles only serves to push back to another stage the point at which legal indeterminacy enters and judicial choice takes place." 50 Furtherinore, they argued that liberal legal theorists had grossly underestimated the degree to which legal language was "open textured" and that, in fact, this language

to legislative judgment, Wechsler was implicitly taking a substantive stand on the issues as he identified them. He assumed that social domination of blacks either did not exist or that sucls a racial regime did not impugn the legitimacy of the legislature.

Id. at 610-12; see also Menscl, supra note 9, at 33.

48. The Crits claim to go "well beyond the version of the indeterminacy argument that everyone professes to accept today-the argument that legal rules do not, of themselves, decide cases" to hold "that the idealized view of the judge as a meclianical lawapplier-and of law as apolitical-is fundamentally and inescapably flawed, because of the very nature of legal discourse and its connection to liuman experience and interaction." Fischl, supra note 12, at 524 .

49. Much of the Critical Legal Studies literature is devoted to demonstrating that there are contradictory principles underlying each of the particular subcategories into which the law is conventionally divided. See generally THE POLITICS OF LAW, supra note 9. However, a central tenet of critical thought is that these particular antinomies merely "reflect a deeper level of contradiction." Duncan Keunedy, Form and Substance in Private Law Adjudication, 89 HARV. L. REV. 1685, 1685 (1976) [hereinafter Kennedy, Form and Substance]. Thus, Robert Gordon asserts that "[t]lie same body of law, in the same context, can always lead to contrary results because law is indeterminate at its core, in its inception, not just im its applications. This indeterminacy exists because legal rules derive froin structures of thought, the collective constructs of many minds, that are fundamentally contradictory." Robert Gordon, Critical Legal Histories, 36 STAN. L. REv. 57, 114 (1984). This "fundamental contradiction" las been described by Duncan Kennedy:

[I]ndividual freedom is at the same time dependent on and incompatible witl the communal coercive action that is necessary to achieve it. ... Only collective force seems capable of destroying the attitudes and imstitutions that collective force has itself imposed. Coercion of the individual by the group appears to be inextricably boimd up with the liberation of that same individual.

Duncan Keunedy, The Structure of Blackstone's Commentaries, 28 BUFF. L. REV. 205, 211-12 (1979) [hereinafter Kennedy, Structure]. The ubiquity of the fundainental contradiction implies that regardless of the type of legal standards being considered, whether rules or principles, "[t]lieir contradictory content, as they atteınpt to embrace both the commitment to autonony and the commitment to community, without any meta-principle to decide when one commitment should prevail over the other, gives them . . . a wholly indeterminate cliaracter." Clare Dalton, Book Review, 6 HARV. WOMEN's L.J. 229, 235 (1983) (citation omitted). For an excellent discussion of the fundamental contradiction, see BELLIOTTI, supra note 10, at 163-66.

50. Altman, supra note 14 , at 217 . . 
was so malleable that judges could always add whatever ideological content they desired. ${ }^{51}$ By thus demonstrating the imeradicable indeterminacy of the law, the Crits claimed to have shown that there could be no principled distinction between legal reasoning and ordinary political debate, i.e., that "law is politics." 52

The Crits regard themselves as more radical than the reahists because they employ the indeterminacy argument to attack the concept of the rule of law itself. They do this on the basis of the "mystification thesis"; the claim that the idea that judges can impersonally and objectively decide cases according to definite criteria serves to mask what is actually occurring-the imposition of the ideological preferences of one group upon the entire community. ${ }^{53}$ According to the Crits, the ideal of the rule of law, of a government of law and not people, "merely cloaks power in the garb of right." ${ }^{24}$ By disguising the value choices inherent in the judicial process, legal rulings are made to look like the necessary outcome of the play of natural forces rather than an exercise of will by those who control the political machinery of society. For the Crits, "the Rule of Law is a mask that lends to existing social structures the appearance of legitimacy and inevitability" and "acts to protect and preserve the propertied interest of vested white and male power. ${ }^{.55}$ Thus, they regard the value of the indeterminacy

51. See, e.g., James Boyle, The Politics of Reason: Critical Legal Theory and Local Social Thought, 133 U. PA. L. REV. 685, 707-08 (1985) (exploring the tension between subjectivism and structuralism, its formative influence upon social theory, and more specifically, upon critical legal thought); Gary Peller, The Metaphysics of American Law, 73 CAL. L. REV. 1152, 1152-53 (1985) (noting that not only must application of legal rules be imformed by policy considerations, but that the application of general policy considerations to a specific case will itself be infused with political considerations ad infinitum). This line of argument is usually associated with the deconstructionist wing of the critical movement. For a good discussion of this type of critique, see J. M. Balkin, Deconstructive Practice and Legal Theory, 96 YALE L.J. 743 (1987).

52. See, e.g. David Kairys, Introduction, in THE POLITICs OF LAW, supra note 9, at 1, 4-5; Allan C. Hutchinson, Introduction, in CRITICAL LEGAL STUdies 4 (Allan C. Hutchinson ed., 1989).

53. See Lawrence B. Solum, On the Indeterminacy Crisis: Critiquing Critical Dogma, 54 U. CHI. L. REV. 462, 463-70 (1987). Among the Crits, commitinent to the claim that the concept of the rule of law disguises the unjust nature of current social arrangements is as close to universal as anything that can be said to be. Virtually all of the critical articles cited to this point contain some version of it. For a good catalog of sources, see id. at $467-68$.

54. David M. Trubek, Where the Action Is: Critical Legal Studies and Empiricism, 36 STAN. L. REV. 575, 595 (1984).

55. Hutchinson, supra note 52 , at $3-4$. 
argument to be that it reveals that the social structure generated by the legal system is not the embodiment of justice it purports to be, but an illegitimate hierarchy.

\section{CRITICAL IMPLICATIONS}

Let us assume that the Crits have been as successful at demonstrating the indeterminacy of the legal standards currently recognized as authoritative as the realists were at demonstrating the indeterminacy of legal rules. Let us further assume that they have demonstrated that the myth that the law is determinate serves to preserve the illegitimate hierarchy of those who currently wield power. ${ }^{56}$ What follows from these assumptions?

At first glance, it might be thought that such a conclusion would drive its proponents toward a radical form of classical liberalism. If the rule of law is mdeed a myth that serves to maintain the illegitimate domination of the politically powerful, justice would seem to require that the role the law plays in the organization of society be shrunk to an irreducible minimum. The essential purpose of the law is to indicate the circumstances under which the state is morally authorized to exercise its coercive power. If the Crits are correct that such authorization can never be ideologically neutral and that the coercion that is in fact authorized invariably serves the interests of the pohtically dominant class at the expense of the rest of society, ${ }^{57}$ it might seem that all that

56. Both of these propositions have been challenged and debated in countless articles critical of CLS and in the Crits' responses. It is not my purpose to rehearse any of this debate here. This article is concerned solely with the implications that can be drawn from these propositions if they are indeed correct. To pursue the substantive debate concerning their truth, a good starting point would be the symposium on critical legal studies in 36 STAN. L. REv. 1 (1984). For an excellent recent treatment of the significance of legal indeterminacy, see Coleman \& Leiter, supra note 17.

57. An extremely clear articulation of this central tenet of critical thought is provided by David Kairys:

The law's ultimate mechanism for control and enforcement is institutional violence, but it protects the dominant system of social and power relations against political and ideological as well as physical challenges. The law is a major vehicle for the maintenance of existing social and povjer relations by the consent or acquiescence of the lower and middle classes. The law's perceived legitimacy confers a broader legitimacy on a social system and ideology that, despite their claims to kinship with nature, science, or God, are most fairly characterized by domination by a very small, mainly corporatized elite.

Kairys, supra note 52, at 7 . See also the invitation to the first CLS conference issued by Mark Tushnet and the conference organizing committee consisting of Professors Abel, Heller, Horwitz, Kennedy, Macaulay, Rosenblatt, Trubek, and Unger, which stated that 
can be done is to restrict the scope of legal regulation as much as possible. This is precisely what classical liberal proponents of the minimal state, such as Robert Nozick, advocate. ${ }^{58}$

This, of course, is not the direction the Crits take. ${ }^{59}$ Unfortunately, due to the wide divergence of opinion among them, it is far from easy to characterize the direction they do take. It has become conventional to divide the Crits into what may be called the mamstream of the movement and its irrationalist or nihilist wing. ${ }^{60}$ Both schools agree on the indeterminacy and inystification theses; both "reject the notion that there is any distinction between law and power and argue that our current legal system supports an illegitimate use of power by some social groups to oppress others. ${ }^{.61}$ However, the nuainstream Crits or rationalists believe in the possibility of reform. They "argue that critical theory can be used to rerationalize mamstream legal doctrine and provide a normative basis for 'reconstruction' after the demise of liberal legalism." ${ }^{.62}$ The irrationahists, on the other hand, reject even the possibility of reform. They clain that "all reconstruction efforts

\footnotetext{
"law is an instrument of social, economic and political domination, both in the sense of furthering the concrete interests of the dominators and in that of legitimating the existing order." See Louis B. Schwartz, With Gun and Camera Through Darkest CLS-Land, 36 STAN. L. REV. 413, 417 (1984) (quoting invitation).

58. See ROBERT NOZICK, ANARCHY, STATE, AND UTOPIA (1974); see also LOREN LOMASKY, PERSONS, RIGHTS, AND THE MORAL COMMUNITY (1987); TIBOR R. MACHAN, INDIVIDUALS AND THEIR RIGHTS (1989); JAN NARVESON, THE LIBERTARIAN IDEA (1988); DOUGLAS B. RASMUSSEN \& DOUGLAS J. DEN UYL, LIBERTY AND NATURE: AN ARISTOTELIAN DEFENSE OF LIBERAL ORDER (1991). For an explanation as to why one unfamiliar with contemporary jurisprudence might be misled into identifying the Crits with the classical liberals, see the discussion of their use of the term "liberation," Kennedy, infra note 69

59. At this point, the obligatory cautionary note concerning the diversity of opinion anong the adherents of the Critical Legal Studies moveinent is in order. Even more than the realists, the Crits are an extrenely diverse group of thinkers. It is often said that the only true generalization that can be made about the Crits is that no such generalization is true (which is, of course, itself false). However, the theorists that $I$ am including under the label of "Crits" for purposes of this article are those who subscribe to both the indeterminacy and mystification theses. This does, in fact, include the majority of the critical thinkers. Beyond the commitment to these two theses, however, any uniformity of thought among the Crits rapidly falls away, as will be made evident below. Therefore, as was the case with the realists, general assertions about "the Crits" should be read as lolding only for those theorists cited in the notes.

60. See Dalton, supra note 49, at 231-39; Minda, supra note 8, at 619-20; Daniel C.K. Clow, Trashing Nihilism, 65 TUL. L. REv. 221, 234 (1990).

61. Chow, supra note 60 , at 234 .

62. Minda, supra note 8 , at 619-20 (footnote omitted).
} 
are doomed"63 and that "no law or legal system can ever be legitimate." ${ }^{\prime 64}$ Let us consider the imphications that each "wing" of the Critical Legal Studies movement draws from the indeterminacy argument.

The inainstream Crits claim that the indeterminacy argument demonstrates the need to einploy the legal system to create a more "democratic" and "egalitarian" society. ${ }^{65}$ They assert that recognition of legal indeterminacy allows us to see the law for what it truly is, a political struggle in which the wrong ideological values have triumphed. Accordingly, they advocate restructuring the legal system so as to ensconce the correct, nonhierarchical values of "humaneness, democracy, community, personal, and collective liberation." ${ }^{66}$ The mainstreain Crits view law as a vehicle

63. Id. at 620 .

64. Chow, supra note 60 , at 234 .

65. See Fischl, supra note 12, at 524.

66. Jay M. Feinman, The Failure of Legal Education and the Promise of Critical Legal Studies, 6 CARDozo L. REV. 739, 757 (1985). As this hist suggests, the mainstream Crits almost invariably express the things they favor in very abstract and general terms. This tendency has made it notoriously difficult to come to grips with their "constructive project." Neither their specific proposals for reform nor the precise nature of the values they wish to instill into the legal system are easy to pin down. This, coupled with their unrelenting critique of existing legal arrangements, has led some traditional legal theorists to dismiss the Crits as cynics with nothing of value to offer the legal community. This view was inost fannously expressed by Paul Carrington, then the dean of Duke Law School, who suggested that the Crits have "an ethical duty to depart the law school, perhaps to seek a place elsewhere in the academy." Paul D. Carrington, Of Law and the River, 34 J. LEGal EDuc. 222, 227 (1984).

The Crits, of course, vehemently reject this characterization. They view themselves as working "toward a world that is more just and egalitarian" by allying their critique of the current state of the law with "a program of 'left' politics." Hutchinson, supra note 52 , at $2-3$. Thus, they describe themselves as placing "fundamental importance on democracy, by which we mean popular participation in the decisions that shape our society and affect our hives." Kairys, supra note 52, at 4-5. See, e.g., Karl E. Klare, Critical Theory and Labor Relations Law, in THE POLMICS OF LAW, supra note 9, at 61, 86 (advocating the transformation of the workplace into "a locus of democratic self-governance"); Gerald E. Frug, The City as a Legal Concept, 93 HARV. L. REv. 1059 (1980) (advocating decentralizing the political system to allow cities to be genume experiments in representative democracy). Further, they see themselves as committed to the egalitarian creation of "nonhierarchical communit[ies] of interest," Gerald E. Frug, Language as Power, 84 COLUM. L. REV. 1881, 1895-96 (1984) (book review), and thus, the empowerment of those oppressed by the current legal system. See Peter Gabel \& Paul Harris, Building Power and Breaking Images: Critical Legal Theory and the Practice of Law, 11 N.Y.U. REV. L. \& SOC. CHANGE 369 (1982-1983). Accordingly, the mainstream Crits lave been generally described as in favor of "participatory denocracy, civic republicanism, or decentralized socialism" based on the value of "the individual's active desire to participate in community life or the value of an institutional framework that systematically reduces eco- 
for social transformation that can be used to cast aside the "patchwork quilt of hiberal pohtics" in order "to make a bigger social bed with more popular bedding." ${ }^{167}$

Initially, the reform project of the mainstream Crits may appear to be internally inconsistent. If by showing the law to be mdeterminate, they have, as they claim, shown it to be an inherently political mechamisin by which dominant social groups illegitimately impose their ideological preferences upon society, how can they advocate its use to produce the egalitarian society they favor? The answer apparently rests on some underlying political assumptions. The Crits believe that unregulated market forces inevitably produce a hierarchical social structure im which the economically powerful are dominant. They attack the liberal legal regime for reinforcing this illegitimate hierarchy. ${ }^{68}$ However, they caimot advocate abandoning the legal regulation of human activity smce this would simply allow the underlying hierarchies to flourish. Thus, for the mainstream Crits, the only alternative is to use legal compulsion to attack the market-generated hierarchies. ${ }^{69}$

nomic inequalities." Note, supra note 8 , at $1682-84$. For a more extensive catalogue of Critical Legal Studies values, see Schwartz, supra note 57, at 435.

67. Hutchinson, supra note 52, at 3.

68. The belief that the law merely reinforces the illegitimate hierarchies inevitably generated by a capitalist system is common to almost all the Crits. In claracterizing the commonalities among the Crits, David Kairys includes the belief that "[t]]he law is a major vehicle for the maintenance of existing social and power relations" and that "it protects the dominant system of social and power relations against political and ideological as well as physical challenges." Kairys, supra note 52, at 7. A statement issued by the Conference on Critical Legal Studies describes CLS as seeking "to explore the inanner in which legal doctrine and legal education and the practices of legal institutions work to buttress and support a pervasive system of oppressive, inegalitarian relations." Peter Fitzpatrick \& Alan Hunt, Critical Legal Studies: An Introduction, in CRITICAL LEGAL STUDIES 1-2 (Peter Fitzpatrick \& Alan Hunt eds., 1987) (quoting statement); see also Dalton, supra note 49, at 230 ("The legal system of late twentieth century America is seen as inextricably linked to the reality of illegitimate hierarchies, whether derived from ownership or control of the means of production, or race or gender discrimination."); Kimberle W. Crensliaw, Race, Reform, and Retrenchment: Transformation and Legitimation in Antidiscrimination Law, 101 HARV. L. REV. 1331, 1366-87 (1988) (arguing that the Crits' focus on deconstruction is unhelpful in improving the political and economic status of Blacks).

69. Duncan Kennedy has provided what is probably the most forceful statement of this approacl:

Only collective force seems capable of destroying the attitudes and institutions that collective force lias itself imposed. Coercion of the individual by the group appears to be inextricably bound up with the liberation of that same individual. If one accepts that collective norms weigh so heavily in favor of the status quo that purely "voluntary" movement is incouceivable, then the only alternative is 
The mamstream Crits have provided many suggestions as to how this may be done. Some have contended that the law should be directly applied to the democratization of social hife. Thus, arguments have been presented to legally require "democratic governance in the workplace" 70 and the decentralization of political power to allow nore effective democratic governance at the city level. ${ }^{71}$ Others assert that the law should be einployed to effect the redistribution of wealtli. On this score, Crit proposals run the gamut from the radical, sucli as that the law effect the transfer of ownership and control of production facilities to workers ${ }^{72}$ or that it read an implied promise into employment contracts transferring

the assumption of responsibility for the totalitarian domination of other peoples' minds-for "forcing them to be free."

Kennedy. Structure, supra note 49, at 212. See also Richard L. Abel, A Socialist Approach to Risk, $41 \mathrm{MD}$. L. REv. 695, 718 (1982) ("Autonomy is not ensured by eliminating political restraints. That is the great myth of liberalism. Economic, social, and psychological constraints are just as important and often more powerful."); Klare, supra note 66, at 84-85 ("[M]y antibureaucratic tone might suggest that my thrust is 'antistatist' or, in current parlance, 'deregulatory.' This is not my intent. In the prevailing political context, deregulation of the workplace (i.e., statutory repeal) means ratification of the preexisting structures of econouric mequality and hierarcly."); Hutchinson \& Monahan, supra note 12, at 236-42 ("[A] powerful state is necessary to fracture existing patterns of social hierarchy and domination.")

Much of the traditional legal community's confusion regarding the mainstream Crits' positive project is due to the Crits' use of terminology. For example, almost all Crits identify themselves as being in favor of "hiberation." To the uninitiated, this term may suggest freedom from governmental coercion, causing them to identify the Crits with the classical liberals as suggested above. See supra text accoinpanying note 58. However, the Crits certainly do not mean the same thing by 'hiberation' that the classical liberals do. What they are referring to is collective or group liberation. For example, Karl Klare points out that "the highest aspiration of democratic culture should be to generate and to nurture in all people the capacity for individual and collective self-governance and selfrealization of their potential." Klare, supra note 66 , at 86 . In rejecting the classical liberal view that liberation is achieved by the law "withering away," he points out that

[t]he difficulty with this perspective is . . a failure to appreciate that politics-the evolving of institutions for organizing peoples' collective, self-directive capacities and for nurturing each person's opportunity for and experience of his or her own potential and of the promise of social living-is an essential component of human freedom.

Id. This point is perhaps made even more clearly by Duncan Kennedy: "We can achieve real freedom only collectively through group self-determination. . . . [This] implies the use of force against the individual." Kennedy, Form and Substance, supra note 49, at 1774. It is clear that to achieve this type of "liberation," the coercive power of the state is indispensable. This accounts for the Crits' willingness to employ the law to realize their values despite their unceasing critique of it.

70. Klare, supra note 66 , at 86 .

71. Frug, The City as a Legal Concept, supra note 66, at 1149-54.

72. See Abel, supra note 69, at 719-44. 
ownership of any closed plant to its present, laid-off, and retired workers, ${ }^{73}$ to the relatively moderate, such as that the income tax be retamed in preference to a consumption tax because of the former's greater effectiveness as a redistributive tool. ${ }^{74}$ Perhaps most significantly, however, many of the Crits argue for the legal empowerment of the subordinated or oppressed groups currently victimized by the "cultural and intellectual hierarchies of the legal system." 75 This line of argument has included arguments for the empowerment of union members, by investing thein with "joint sovereignty" with management over investment and other decisions that affect the competitive position of the firm; ${ }^{76}$ of woinen, by altering state laws concerning working conditions and child care to aid working mothers in maintaining their careers, ${ }^{77}$ extending the scope of antidiscrimination statutes froin the workplace into the private sphere, ${ }^{78}$ and shrinking the defense of consent in cases of rape ${ }^{79}$ of racial minorities, by making the law explicitly race-conscious ${ }^{80}$ or instituting programs of large-scale affirmative action, ${ }^{81}$ and of oppressed people generally, by using the law to build "an authentic or unalienated political consciousness."

Unlike the inamstream Crits, the irrationalists offer no specific program for legal reform. ${ }^{83}$ This is because, as their designation

73. See Duncan Kennedy, Distributive and Paternalist Motives in Contract and Tort Law, With Special Reference to Compulsory Terms and Unequal Bargaining Power, 41 MD. L. REV. 563, 629-31 (1982).

74. See Mark Kelman, Time Preference and Tax Equity, 35 STAN. L. REV. 649 (1983).

75. Minda, supra note 8 , at 621 .

76. See Katherine Van Wezel Stone, The Post-War Paradigm in American Labor Law, 90 YALE L.J. 1509, 1558 (1981).

77. See Mary Joe Frug, Securing Job Equality for Women: Labor Market Hostility to Working Mothers, 59 B.U. L. REv. 55 (1979).

78. Nadine Taub \& Elizabeth M. Schneider, Women's Subordination and the Role of Law, in THE POLITICS OF LAW, supra note 9, at 151, 154-57.

79. See Mark Kelman, Interpretive Construction in the Substantive Criminal Law, 33 STAN. L. REV. 591, 614-15 (1981). 68.

80. See Gary Peller, Race Consciousness, 1990 DUkE L.J. 758; Crenshaw, supra note

81. Duncan Kennedy, A Cultural Pluralist Case for Affirmative Action in Legal Academia, 1990 DUKE L.J. 705.

82. Gabel \& Harris, supra note 66 , at 375 .

83. In what follows, I present only a cursory overview of the irrationahist position. To even approach an adequate treatment of this position would require a detailed exegesis on complex metaphysical and epistemological positions quite beyond the scope of the present work. For an excellent discussion of the philosophical foundations of the irrationalist position, see Chow, supra note 60 . 
suggests, they believe that reason is impotent to resolve legal and moral issues. Heavily influenced by the plilosophy of Richard Rorty ${ }^{84}$ and the deconstructionist school of hiterary criticism associated with Jacques Derrida, ${ }^{85}$ the irrationalists believe that objective knowledge is impossible. Following Rorty, they reject the correspondence theory of truth that holds that a statement is true when it is an accurate representation of an underlying reality. ${ }^{86}$ They assert that since it is impossible "to step outside our skins - the traditions, linguistic and other, within which we do our thinking and self-criticism-and coinpare ourselves with something absolute," ${ }^{87}$ reality is socially constructed, i.e., the result of social practices that "embody contingent choices concerning low to organize the thick texture of the world in consciousness." 88 Thus, the irrationalists adopt the coherence theory in which "the meaning of words are not determined by external referents, but instead by their coherence with other words or judgments within our total body of knowledge." 89 This, however, implies that "the attempt to fix the meaning of an expression leads to an infinite regress," $" 90$ and hence, that "meaning is ultimately indeterminate." Since this is true generally, it obviously inust be true within the legal realm as well. ${ }^{92}$ Therefore, for the irrationahists, the indeter-

For the purposes of the present discussion, I will take the following works to be representative of the irrationalist wing of CLS: Joseph Willam Singer, The Player and the Cards: Nihilism and Legal Theory, 94 YALE L.J. 1 (1984); Peller, supra note 51; Boyle, supra note 51. For an extended list of irrationalist writings, see Chow, supra note 60, at 223-24 n.4.

84. See Richard Rorty, PHILOSOPHY AND tHe MirRor of NATURe (1979); RichARD RoRTy, THe CONSEQUENCES OF PRAGMATISM (1982) [hereinafter RoRTY, PRAGMATISM].

85. See JacQues DeRrida, OF GRAmmatology (1976).

86. See Chow, supra note 60, at 259-65.

87. RORTY, PRAGMATISM supra note 84 , at xix.

88. Peller, supra note 51, at 1169 (citation omitted). Peller explains:

[O]bjects are constructed as they are perceived since perception itself occurs through the medium of representational categories. Knowledge does not flow from a free subject perceiving independently existing objects; it is constructed in the relationships between things, in the metaphors we create. . . . Hence, "reality" is not an objective realm existing independent of representational practices. "Reality" is not carved up into categories that representational systems happen to match. Rather, "reahity" is constructed in the very process of description or representation.

Id. at 1170-76 (footnote omitted).

89. Chow, supra note 60 , at 275.

90. Peller, supra note 51, at 1167.

91. Id. at 1169.

92. As Chow explains, "Since it is impossible to trace all of the interconnections of 
minacy of the law is merely a consequence of the inherent indeterminacy of human language. ${ }^{93}$

This philosophical position, which has been described as radical subjective idealism, ${ }^{94}$ leads the irrationalists to embrace an extreme form of epistemic skepticism in which "it is impossible to say anththing true about the world." 95 This, of course, entails a commitment to ethical relativism such that "[a]ny action may be described as right or wrong, good or bad." ${ }^{.96}$ Thus, for the irrationalists, reason is irrelevant to our normative pursuits. Since there are no objective moral or legal truths, reason cannot help us find thein: "[L]egal and moral questions [are] matters to be answered by experience, emotion, introspection, and conversation, rather than by logical proof."

[w] hen judges decide cases, they should do what we all do when we face a moral decision. We identify a himited set of alternatives; we predict the most likely consequences of following different courses of action; we articulate the values that are important in the context of the decision and the ways in which they conflict

words throughout the entire system of beliefs, the meaning of any one word always remains indeterminate. If the meaning of any word, the building blocks of legal reasoning, is indeterminate, then legal reasoning itself is indeterminate." Clow, supra note 60, at 275.

93. For the irrationalists, both the indeterminacy and mystification theses essentially fall out of their underlying epistemological position. According to Peller, the liberal mindset is the result of what Derrida calls "the metaphysics of presence," DERRIDA, supra note 85 , at 49 , in which "the artifactual character of representational categories utilized in purportedly rational thought processes is denied." Peller, supra note 51, at 1168-69. As he puts it, "The purported distinction in liberal thought between reason and will-and, I will contend, law and politics-depends on the denial of the contingency of representational categories." Id. at 1168.

For an excellent account of the derivation of the irrationalist position, see Chow, supra note 60 , at $275-77$.

94. Chow, supra note 60 , at 259.

95. Singer, supra note 83 , at 4 . According to Singer, "No one can properly claim to describe the world accurately: Anything anyone says is as likely to be wrong as it is to be right, and anything is as likely to be right or wrong as anything else." Id.

96. Id.

97. Id. at 56 (footnote oumitted). For the irrationalists, noral and legal decisions have the saine character as decisions as to whether "to get married, to have children, to go to law scliool, to move to another state, [or] to quit their jobs." Id. at 62 . To make such decisions, people do not reason their way to a resolution; they simply choose. They "think long and hard about what they want in life; they imagine what their lives would be like if they were to follow one path rather than another; they talk with the people who are most important to them and whose opinions they valne; they argue with others and with themselves; and in the end, they make a decision." Id. 
with each other; we see what relevant people (judges, scholars) have said about similar issues; we talk with our friends; we drink enormous amounts of coffee; we choose what to do. ${ }^{98}$

For the irrationalists, the function of legal theory is essentially "expressive rather than determinative." 99

For this wing of the CLS movement, the implication of the indeterminacy argument is that all legal judgments must be made intuitively. ${ }^{100}$ However, they regard this as cause not for concern, but for celebration. They believe that once human beings come to see that "all aspects of social life, including laws and legal institutions ... are socially constructed," they will feel "free to restructure or reject all of them."101 This, in turn, will liberate them to develop and embrace their own "passionate moral and political commitments,"102 and the conconitant recogmition that eacl of thein bears responsibility for all - sucl choices ${ }^{103}$ will empower them "to become the rulers of [their] own destin[ies]." 104 Thus, for the irrationalists, our acknowledgment of the indeterminacy of the law gives rise to a profoundly lopeful experience. ${ }^{105}$

98. Id. at 65 .

99. Id. at 63.

100. Since "general social-theoretical explanations are unavailable," these intuitions will apparently arise out of one's immersion in "minutely detailed maps or descriptions of phenomena." Mark Tushnet, Critical Legal Studies: An Introduction to its Origins and Underpinnings, 36 J. LEGAL EDUC. 505, 513 (1986).

101. Chow, supra note 60 , at 227.

102. Singer, supra note 83 , at 9 .

103. See id. at 66 .

104. Chow, supra note 60 , at 227 . Indeed, since the Crits see liberalism as responsible for creating a culture of alienated and lonely individuals in continual competition with one another, see Singer, supra note 83 , at 69 , they regard the very process of critique as a liberating experience. As Clare Dalton expresses it,

Imagine critique as a powerful device for stripping away from us, if we cloose, the legal abstractions by which we order our perceptions, leaving us groping, to be sure, but forced to deploy whatever other means of decisiou are available to us, and with at least a hope of making something new of our experience . . . . Imagine the possibility that those who embraced the experience, and felt changed by it, would feel the desire to act with others towards social transformation in the name of a contingent commitunent to association rather than isolation and conflict.

Dalton, supra note 49 , at $241-42$.

105. The irrationalist position has frequently been criticized as being incoherent or, at least, self-defeating. It is not my purpose to pursue this criticism here. I should point out, lowever, that although the irrationalists behieve that all people must make moral and legal decisious on the basis of their intuitions, they seem to suggest that these intuitions should be arrived at on the basis of conversing with others, reflecting on experience, and imagining the consequences of the decision. See Singer, supra note 83 , at 62,65 . If they 


\section{Realist CRItique}

The Crits are conventionally regarded as the intellectual descendants of the legal realists, ${ }^{106}$ and with respect to their deployment of the indeterminacy argument against the formahism they found in the post-reahst legal universe, this is an apt description. However, when we consider the implications that the Crits draw from legal indeterminacy, the family resemblance quickly fades. To see why, recall that the reahsts had introduced the indeterminacy argument to direct the legal community's attention toward the einpirical effects of legal decisions and enactments on the hives of the human beings to be governed by them. They attacked the formalisin of their day for rendering legal judgments on the basis of the logical relationships among abstract concepts, i.e., transcendental nonsense, rather than in terms of the judgments' actual effects: ${ }^{107}$ To the realists, the indeterminacy argument was a clarion call for a pragmatic approach to law. ${ }^{108}$ This, however, is precisely the approach that Crits reject.

do in fact make such a suggestion, then, given their position, it is not at all clear what can be meant by the word "should" in the previous sentence or how this suggestion can be maintained in the face of those individuals whose intuitions tell them that conversation and reflection are irrelevant and that all who disagree with them inust be violently suppressed. This, however, represents the topic of another article. To pursue this line of objection, see BELLIOTI, supra note 10, at 169-73; Chow, supra note 60, at 277-98; Coleman \& Leiter, supra note 17, at 601; Hutchinson \& Monahan, supra note 12, at 236-42; Joan C. Williams, Critical Legal Studies: The Death of Transcendence and the Rise of the New Langdells, 62 N.Y.U. L. REV. 429, 480-481, 488-91 (1987). See generally Phillip E. Johnson, Do You Sincerely Want to Be Radical?, 36 STAN. L. REv. 247, 249 (1984) (claiming that Critical scholarship has proved to be an "inadequate response" to limitations of liberal politics); Schwartz, supra note 66, (noting several such inconsistencies in tenets of CLS scholarship).

106. See, e.g., Minda, supra note 8, at 636; Note, supra note 8, at 1669, 1682.

107. See supra notes 19-22 and accompanying text.

108. The realists' emphasis on an empirical approach to law was an outgrowth of their underlying pragmatic philosophy. See GEORGE CHRISTIE, JURISPRUDENCE 643 n.13 (1973); Singer, supra note 9, at 474. Sec generally Kenneth M. Casebeer, Escape from Liberalism: Fact and Value in Karl Llewellyn, 1977 DUKE L.J. 671. For the pragmatists, knowledge consists in "understanding the consequences of loolding the views we have and recognizing what it takes to achieve the goals we espouse." Trubek, supra note 54, at 581. Thus, "[f]or the pragmatists, the pattern of all inquiry-scientific as well as moral-is deliberation concerning the relative attractions of varions concrete alternatives." RORTY, PRAGMATISM, supra note 84 , at 164 . For the realists, this meant that factual inquiry was indispensable to legal analysis since "law cannot be defined other than by the difference it makes in society, and empirical inquiry is necessary to determine what that is." Trubek, supra note 54 , at 581 . 
The Critical Legal Studies movement was formed as a reaction against the empirical orientation of the Law and Society Association. ${ }^{109}$ The Crits broke off from this group because of their belief that "the Association had become too closely identified with the 'empirico-behaviorist' wing of social science and that the road to jurisprudential enlightenment lay down a less data-oriented, more theoretical path." ${ }^{110}$ The Crits became the Crits specifically because of their desire to engage in doctrinal analysis at the more abstract level of social theory. ${ }^{111}$ Their interests lay not in the study of low the law functions, but in the "dissect[ion of] the presuppositions and ideologies immanent in the legal order." Thus, in order to attack the premises of liberal legalism "at higher and higher levels of generality,"113 the Crits abandoned the study of "the gap between the law in the books and the law in action"114 for that of social theory, metaphysics, and epistemology.

For this reason, I suspect that although a resurrected reahist might well be proud of the way in whicl his intellectual descendants liave stripped away a new layer of legal formalisin, he would be chagrined by their complete lack of attention to the practical implications of having done so. For, in surveying the contemporary jurisprudential literature, he would notice that after demonstrating how a given aspect of the liberal legal system works to maintain the dominance of an illegitimate hierarchy, the Crits then simply assnme that whatever they recommend will end this dormination and create a inore egalitarian society. Although he would find calls for "utopian speculation," things might be better than they are,"116 and for "imagin[img] a better life in the context of living with others,"117 he would also find that the proposals that emerge from such imaginings "are not accompamed by any cost-benefit analysis, comparison of alternative courses, or discussion of the necessary institutional arrange-

109. See Hutchinson \& Monahan, supra note 12, at 200.

110. Id.

111. See id. at 213-19.

112. Note, supra note 8 , at 1680 .

113. Id. at 1681 .

114. Trubek, supra note 54, at 589. Trubek provides an excellent account of the divergence between the methodology of the realists and that of the Crits.

115. Duncan Kennedy, Cost-Reduction Theory as Legitimation, 90 YALE L.J. 1275, 1283 (1981)

116. Id.

117. Singer, supra note 83 , at 66 . 
ments." 118 In short, he would find that "CLS scholars assume rather than investigate the relationship between ehte legal ideological production and social action ... [ [and are] relatively indifferent to most of the literature on law and society that does try to explore the impact (or lack thereof) of legal rules, doctrine, and institutions." 119

With regard to the mainstreain Crits, such a realist might point out that despite decrying the legal formahism of the liberal regime, these scholars seem to derive their constructive agenda from a newly-minted political fornalism rather than from any consideration of the law's actual effects. ${ }^{20} \mathrm{He}$ might note that although they excoriate liberals for deriving conclusions of law from the manipulation of legal abstractions such as "liberty, freedom of contract, and property,"121 these Crits themselves derive political conclusions from the manipulation of political abstractions such as "democracy," "egalitariarnsm," "liberation," "hierarchy," "domination" and "subordination." For exainple, based on the political assumptions that an unregulated free market would produce a hierarchical society in which women and people of color were subordinated and that the hiberal legal system reinforces rather than establishes this hierarcliy, they simply declare that the extension of antidiscrimination laws imto the private realm ${ }^{122}$ or the mitiation of explicitly race-conscious affirmative action progranis ${ }^{123}$ would be an effective step toward the liberation of these groups and the production of a more egalitarian and democratic society. Our revi-

118. Schwartz, supra note 57 , at 427 .

119. Trubek, supra note 54, at 615 . Indeed, the Crits themselves often exphicitly recognize this indifference. Karl Klare states that "an important limitation of the critical labor law approach is its relative neglect, thus far, of the important task of drawing out empirically the interrelationships and connections between the intellectual history of collective bargaining law and the social history of the post-World War II labor moveinent." Karl $E$. Klare, Labor Law as Ideology: Toward a New Historiography of Collective Bargaining Law, 4 INDUS. REL. L.J. 450, 452 n.6 (1981); see also Kennedy, Structure, supra note 49, at 220 ("[W]hat I have to say is descriptive, and descriptive only of thought. It means ignoring the question of what brings a legal consciousness into being, what canses it to change, and what effect it has on the actions of those who live it.").

120. This critique is initially addressed only to the mainstream Crits since there is a sense in which it is true to say that the irrationalists have no constructive agenda. However, I will suggest below that it can be extended to the irrationalist position as well. See infra text accompanying notes 127-129.

121. Note, supra note 8 , at 1679.

122. See Taub \& Schneider, supra note 78.

123. See Kennedy, supra note 81 . 
vified realist might suggest that in the absence of some evidentiary support for these claims, the inainstream Crits are simply talking transcendental nonsense.

The realist would contend that in order to evaluate the desirability of any legal provision, one must descend from the realm of political abstraction to the world of the empirically verifiable and do the hard work of determining what effects that provision actually produces. ${ }^{124} \mathrm{He}$ would surely point out that "relations between elite doctrine and social behavior cannot be assumed $a$ priori." 125 For example, to determine whether the antidiscrimination laws should be extended or new affirmative action programs instituted, one would have to ask questions such as the following: To what degree is the subordination of women or people of color attributable to market forces and to what extent is it attributable to the effect of past and present legal restrictions on the operation of such forces? What are the interests of the bureaucrats at the Equal Employment Opporturnty Commission or a new Commission for the Empowerment of Woinen and People of Color and how are they likely to influence the way in which the law is interpreted? What effect will the enforcement of these measures actually have on the status of women and minorities? To what degree will it cause them to be treated with lieightened respect and consideration and to what degree will it cause them to be treated with suspicion and resentment? How do the long-term results of imposing these legal prohibitions compare with those of leaving the field unregulated? ${ }^{126}$ Simce the mainstreain Crits do not ap-

124. Indeed, it has been suggested that this is precisely the type of work the Crits have reason to avoid. As David Trubek explains,

Most Critical legal scholars are legal educators. ... They spend their working hives in settings that stress the importance of legal texts. Many work in schools that are largely isolated both from the day-to-day world of legal practice and from other academic disciplines. All these factors help explain why, even though contextual studies of law and legal thonght in action form a necessary part of a genuine program of Critical thonght on law, such studies are rarely produced.

Trubek, supra note 54 , at 618 .

125. Id. at 612. The Crits' tendency to make a priori assumptions has itself been seen as an argument against their agenda. Thus, Phillip Johnson argues:

This refusal to address the pragmatic issue . . . is typical of Critical legal scholarship, and explains why this kind of writing is so unsatisfying to persons of a practical bent. If the Critical scholars are making the point that utopian fantasy is the only alternative to conventional legal thought, then they are making the strongest possible pragmatic argument for inaintaining our conventions.

Johnson, supra note 105 , at 262.

126. The Crits have frequently been criticized for mischaracterizing the nature of 
pear to have addressed any of these questions, our reahst critic would probably accuse them of doing nothing more than substitutmg one form of transcendental nonsense for another. And since the realists introduced the indeterminacy argument in order to force lawyers to evaluate the law in terms of its actual effects on human beings, I suspect that he might also suggest that these Crits have simply missed the point of that argument.

Of course, the realist's critique would not be limited to the mainstream Crits. Although the irrationalist Crits offer no specific proposals for legal reform and declare that legal judginents must be made intuitively, they are not recommending that sucl judgments be made blindly. The irrationalists are not calling upon judges, lawyers, and legal scholars to resolve difficult legal issues on the basis of ill-considered whims or by flipping a coin. Rather, they believe that such judgments should be made by reflecting upon what one wants in life, by imagining what life would be like were one to decide one way rather than another, and by engaging in discussions with people whose opinions one values. ${ }^{127}$ They

unregulated human interaction. For example, Louis Schwartz points out that the Crits tend to identify liberal society with the hberal legal system, wholly ignoring nonlegal influences on human behavior. Thus, in response to Duncan Kennedy's claim that the hiberal regime allows individuals "total arbitrary discretion. .. [to act] without regard to the impact of their actions on others. . . . A can let B starve, or, indeed, kill lim, so long as this can be accomplished without running afoul of one of the limits of discretion" and "without acknowledging any interdependence whatever as moral beings," Kennedy, Form and Substance, supra note 49, at 1768, Schwartz points out that "[c]riticizing the law's failure to demand altruism, self-sacrifice, or heroism is easy if one assumes that tradition, religion, family, patriotism, education, and charity are not part of our socialization. Such an assumption, however, is wholly invalid." Schwartz, supra note 57, at 433. Schwartz goes on to suggest that

virtually all CLS writing ignores the nonlegal influences in society that conduce strongly towards mutual aid, charity, and the like. It may also illustrate the hazards of nriddle-class writing about how most people behave. Middle-class people have fewer occasions to render Critical assistance; anyone who knows the poor must recognize their proclivity to mutual aid.

Id. at 445. This constitutes a specific example of the broader criticism frequently directed against the Crits of failing to consider alternatives to their proposals. As Phillip Johnson expresses this criticism,

Critical scholars who describe "capitalist" society as oppressive or hierarchical are like New Yorkers who speak of Cleveland as being in the "West." Contemporary capitalist society may be oppressive and hierarchical judged by some ideal standard and yet have less oppression and hierarchy than inost or even all other societies that have ever existed. Critical legal writing systematically evades the question, "Compared to what?"

Johnson, supra note 105 , at 260.

127. See Singer, supra note 83 , at 62 . 
are calling for decisions to be made on the basis of a considered intuitive judgment, one that is informed by "experience, emotion, introspection, and conversation." 128

Given this, our reakist critic would probably suggest to the irrationahists that even if they are correct in calling for imtuitive legal decisionmaking, more is required than inerely imagining what the consequences of one's decisions will be. He would probably point out that if the irrationahists wish judges to base their decisions even partially on "predict[ions of] the most likely consequences of following different courses of action,"129 judges would seem to have an obligation to procure some enpirical information about these consequences. He might also suggest that to the extent that one is to base his or her decision on conversations, such conversations are likely to be more productive if one has acquired soine information to converse about. Thus, the realist would contend that if the irrationalists want their legal decisions to be distinct froin inere random guesses, they, too, have an obligation to study the relationship between their proposed solutions and those solutions' actual effects. Until they begin to pay attention to such inatters, I suspect that our realist critic would accuse the irrationalists of talking transcendental nonsense just as much as the mainstream Crits, and, like them, to have missed the essential point of the indeterminacy argument.

In sum, I beheve our reanimated realist might suggest to all Crits that they pay closer attention to the words of one of their own, Roberto Unger, who warned that "[o]ne passes all too easily from remorseless savagery in the criticism of the past to child-like innocence in the anticipation of the future." 130

\section{BACK TO THE FUTURE: \\ Public CHOICE AND THE REAIIST PROJECT}

Our realist critic has suggested to the Crits that if they really beheve that the indeterminacy argument establishes that "law is pohtics," then they should be concerned with the ways in which the pohtical process actually works. Although, to date the Crits have been uninterested in pursuing this line of inquiry, there is

128. Id. at 56 .

129. Id. at 65 .

130. ROBERTO M. UNGER, KNOWLEDGE \& POLITICS 284 (1975). 
another group of contemporary theorists who do precisely that. These are the public choice scholars. ${ }^{131}$

These scholars are a group of economists, pohtical scientists, and lawyers who examine the actual processes by which law is both made and put into effect. While recognizing that real world market economies are "replete with market failure,"132 these theorists make no attempt to develop ideal "solutions,' which in turn would be faithfully adopted by democratic governments to promote the general welfare."133 Rather, they see their role as developing an understanding of the actual functioning of the pohtical process in order to accurately compare what emerges from it with the results of market forces. Or, as expressed by a leading article on the subject, "If we want to know if and when government can be expected to yield preferable outcomes compared to the market, we must systematically analyze how the pohtical process works. This is precisely what public choice theory does."134

Begimning with the assumption that "the men and women working in government as politicians and bureaucrats are pretty much the same as their counterparts in the private sector,",135 the public choice scholars regard the government neither as "some orgamic entity that always makes decisions in the public interest [nor] ... as a mechanism that automatically corrects the failings of the market process," 136 but as "a set of processes by which people relate to one another."137 Viewed in this way, "[g]overnmental decisions and policies are simply the outcomes of the interactions of the people who relate to one another through a particular

131. I must now issue another disclaimer regarding the diversity of opinion anong the groups of theorists to which I am assigning labels. Like the realists and Crits, the public choice scholars represent a widely diverging set of viewpoints. Although they probably have more in common than either of the other groupings of theorists examimed so far, there clearly is no such thing as a uniform body of public choice doctrine. In this article, my comments will inost often reflect what has coine to be known as the "Virginia School" of public choice theory. However, as before, the ascriptions made to the "public choice theorists" should be read as holding only for those actually cited in the notes.

132. James Gwartney \& Richard E. Wagner, The Public Choice Revolution, 23 INTERCOLLEGIATE REVIEW 17, 17 (1988).

133. Id.

134. Id.

135. Id. at 18 .

136. James Gwartney \& Richard E. Wagner, Public Choice and The Conduct of Representative Government, in PUBLIC CHOICE AND CONSTITUTIONAL ECONOMics 3, 6 (James Gwartney \& Richard E. Wagner eds., 1988).

137. Gwartney \& Wagner, supra note 132 , at 17. 
political system or constitutional order." ${ }^{\text {138 }}$ By taking this perspective, public choice theorists hope to achieve "the design of improved governmental methods based on the positive information about how governments actually function." 139

From this, it should be apparent that the public choice scholars are as inuch the intellectual descendants of the realists as are the Crits. Whereas the Crits are credited with reinvigorating and extending the realist critique of legal determinacy, the public choice scholars may be seen as reinvigorating and extending the realists' pragmatic approach to law in both its descriptive and normative dimensions. Recall that on the descriptive level, the realists insisted that attention be directed toward the law as applied rather than the law as written. Rejecting the idea that "all one needs to do in order to know the effects of a given rule is to read the rule and to appreciate its purpose, ${ }^{, 140}$ the realists called for the study of the law that einerges froin the political and interpretative process-the law as it actually impacts upon the public. ${ }^{141}$ This is a inajor part of what public choice scholars working on the theory of bureaucracy do. ${ }^{142}$ Their main object of study is the way the law as written is translated into action by those charged with its implementation. Furthermore, the reahists' normative program was based upon recognizing the law for what it is-one among many methods

138. Id.

139. Gordon Tullock, Public Choice, in 3 THE NEW PALGRAvE: A Dictionary of ECONomics 1040, 1041 (John Eatwell et. al. eds., 1987). See also Geoffrey Brennan \& James M. Buchanan, Is Public Choice Immoral? The Case for the "Nobel" Lie, $74 \mathrm{U}$. VA. L. REv. 179, 187 (1988).

140. COHEN, supra note 14 , at 87.

141. The realists described themselves as skeptics who demand hard coin of social fact in place of paper legalities. Some of these skeptics have suggested that the words of a statute often lave only the most superficial resemblance to the workings of the statute. A good deal of statute law turns out under investigation to be without any force-law-in-books rather than law-in-action; other parts of the statute law have been given new meanings in judicial, administrative, and popular construction-meanings that could never have been deduced from the words of the legislature. In either case, study of the statutes fails to provide a realistic picture of functioning law.

Id. at 81 .

142. See anthony Downs, Inside Bureaucracy (1967); William Niskanen, BuREAUCRACY AND REPRESENTATIVE GOVERNMENT (1971); GORDON TULLOCK, THE POLITICS OF BUREAUCRACY (1965). 
of bringing order to the community - with its own set of comparative advantages and disadvantages. ${ }^{143}$ This implied that it had to be evaluated first in terms of what it was actually capable of accomplishing ${ }^{144}$ and then on the basis of whetleer it could accomplish this better than any of the other available mechanisms of social control. ${ }^{145}$ But this is the essence of the public clioice program. By studying the effects of phenoinena such as the average person's "rational ignorance," 146 the influence of special interests, ${ }^{147}$ the incentives to engage in rent-seeknig behavior, ${ }^{148}$ the different time lorizons for private versus collective cloice, ${ }^{149}$ and the difference between political and private transaction costs, ${ }^{150}$ these scliolars are attempting to determine both what it is possible to accoinplish through political action and the extent to which such ends could be better achieved through nonpolitical means.

143.

The law is one among many "control" institutions. The direction of its powers is largely determined by a process of competition with organized religion, organized education, the family, professional and mercantile agencies of control, and various other social institutions, each with its own "inner order" and its own sanctions. The disruption of any of these agencies throws new tasks upon the law; their development relieves the legal order of old responsibilities.

COHEN, supra note 14, at 91 (citation omitted).

144.

The luman significance of any rule of law thus depends upon the extent to which it secures obedience. This, im turn, will depend upon the strength of the organized desire for which the rule provides an enforcing instrument, as compared with the strength of the organized desire which the rule is intended to frustrate. The failure to recognize this persistent struggle that underhes all law enforcement is written large in the history of social reform legislation. Again and again idealists lave succeeded in writing their hopes on the statute books, only to discover in dismay that laws are not self-executing. ... What the law ought to accomplish in any given situation cannot be determined without determining what the law can accomplish.

Id. at $89-90$.

145. "In this competition with other organizations of social force, the law realizes the limitations of its machinery." Id. at 91.

146. See ANTHONY DOWNS, AN ECONOMIC THEORY OF DEMOCRACY 238-59 (1957).

147. See Michael A. Brooks and Ben J. Heijdra, In Search of Rent-Seeking, in THE POLITCAL ECONOMY OF RENT-SEEKING BeHAVIOR 35-39 (Charles K. Rowley et al. eds., 1988).

148. See id; Gordon Tullock, The Welfare Costs of Tariffs, Monopolies, and Theft, 5 W. ECON. J. 224 (1967).

149. See Dwight R. Lee \& Richard B. MCKenzie, Regulating Government: A PREFACE TO CONSTITUTIONAL ECONOMICS 127-31 (1987).

150. See Charlotte Twight, Political Transaction-Cost Manipulation: An Integrating Theory, 6 J. THEORETICAL POL. 191 (1994); Charlotte Twight, Government Manipulation of Constitutional-Level Transaction Costs: A General Theory of Transaction-Cost Augmentation and the Growth of Government, 56 PUB. CHOICE 131 (1988). 
However, if this shows that the Crits and public choice scliolars share a bond of consanguinity, it also shows this relationship to be one beset by serious sibling rivalry. To see this, consider that public choice theory may be seen as at least iniplicitly criticizing the traditional approach to economics for dwelling upon abstractions sucl as the perfectly competitive market or homo economicus rather than the analysis of the way actual human beings function in real world economic and political systems. ${ }^{151}$ In this respect, public choice scholars seem to eclio not only the realists' criticisin of nineteenth century legal formalism, but also our inıaginary realist's critique of today's Crits. Indeed, since the Crits believe that law is politics, and politics is precisely what public cloice scholars study, it is not unreasonable to view the challenge the public choice scliolars present to traditional economics as a challenge to the Crits as well. ${ }^{152}$

If this is so, then the public clioice scholars may be scen as standing in the same relationship to the Crits as the realists did to the legal formalists. Whereas the realists castigated the formalists for basing legal decisions on the manipulation of legal abstractions rather than the actual effects of the decisions on liuman beings, the public choice theorists inay be viewed as castigating the Crits for basing political decisions on the mampulation of political abstractions rather than the actual effects of the decisions. Public choice declarations that theorists "who formulate optimizing solutions to market failure that are inconsistent witl the operation of political organization inight as well be spending their time working crossword puzzles"153 and that "[e]xpected outcoines under market organization ... must be coinpared with expected outcomes under political organization ... [to avoid being] like the judge who after liearing the first contestant sing, immediately declared the second contestant the winner,"154 sound hauntingly like the realist critique of legal formalism.

151. See Brennan \& Buchanan, supra uote 139 , at $179-81$.

152. It is important to note that I am not suggesting that any public choice scholar has actually made this or any other criticism of the Crits. Both here and throughout this article generally, I am describing what $I$ believe public choice scholars would say to the Crits if they were to address them. I am not aware of any public choice scholar who has, in fact, done so as yet.

153. Gwartney \& Wagner, supra note 132, at 23.

154. Id. 
This, of course, does not establish that there is anything wrong with the Crits' proposals; it merely implies that, at present, they are based upon unsubstantiated assumptions. However, recent public choice scholarship has provided reason to doubt several of these assumptions. Consider, for example, the Crits' argument for legal action to empower people of color. One of the assumptions upon which this argument rests is that the liberal legal regime merely reinforces the subordination of such people that is produced by market forces. ${ }^{155}$ This behef that the inarket is itself racially oppressive leads to the conclusion that merely repealing all racially oppressive laws would be insufficient to end this subordination. However, public choice theorist Jennifer Roback's studies of the political and economic forces responsible for the rise of "Jim Crow" legislation in the post-Civil War Soutli ${ }^{156}$ and the political logic of racism ${ }^{157}$ suggest that the reverse may be the case.

In her examination of conditions immediately following the Civil War, Roback found that because the emancipated slaves had superior knowledge of agricultural techinques and because of the shortage of young white men due to the ravages of the war, Southern blacks had considerable market power. Their value as agricultural laborers was sucl that attempts by white landowners to form collusive agreements to suppress their wages invariably failed due to the competitive advantage each could gain by defecting. ${ }^{158}$ It was precisely the market's resistance to such efforts to subordinate African-Americans that led to political agitation for antiblack "Jim Crow" legislation. As Roback documents, this agitation led to the passage of highly restrictive labor legislation througliout the Soutl that "can best be understood as attempts to enforce a

155. See, e.g., Kennedy, supra note 81 ; see also supra p. 27.

156. See Jennifer Roback, Southern Labor Law in the Jitn Crow Era: Exploitative or Competitive?, 51 U. CHI. L. REv. 1161 (1984) [hereinafter Roback, Jim Crow]; Jennifer Roback, The Political Economy of Segregation: The Case of Segregated Streetcars, 46 J. ECON. HIST. 893 (1986) [hereinafter Roback, Segregated Streetcars].

157. Jennifer Roback, Racism as Rent Seeking, 27 ECON. INQUIRY 661 (1989). 158.

Throughout the period, we read of white planters pleading with one another to hold down black wages. "White men have to stick together" was the common theme. Despite all these admonitions, white employers vigorously competed with one another for black labor, and there are numerous reports of blacks leaving jobs to take higher-paying opportunities.

Roback, Jim Crow, supra note 156, at 1161. 
labor-market cartel among white employers that could not be enforced in any other way." 159 As she explains

The planters wanted to collude to hold down black wages, both to increase their own profits and to solidify the dominant position of the white race. But ... economic class interest and white soldarity were not adequate to overcone the economic incentive for individual planters to offer higher wages to blacks. The laws were intended to accomplish what race prejudice could not do by itself. ${ }^{160}$

In addition, Roback discovered that Jim Crow legislation requiring the segregation of public transportation not only was not an outgrowtl of market forces, but that it had to be imposed over the strenuous objection of the business community which, lowever racist it may have been, did not want to incur the costs associated with the provision of segregated services. ${ }^{161}$ As she points out, lad market forces favored segregation, the railway companies could easily have adopted such a policy without legislation. ${ }^{162}$ But, although the costs associated witli the provision of segregated services might have been prolibitive for private businesses, this was not the case for "political entrepreneurs," i.e., politicians who could make political capital out of white racism. Roback suns up the political logic of the situation as follows:

White passengers seemed to be indifferent about segregation; streetcar coinpanies resisted segregation; certainly black passengers resisted segregation. Who then wanted it badly enough to work for its introduction? The most likely candidates are politicians who believed that there existed latent sentiment in favor of segregation anong whites. Political entrepreneurs could offer white voters something they valued enough to vote for, but not enough to bear the costs privately. Through collective action, the costs of segregation could be imposed on the (disenfranchised) black passengers and the (regulated) streetcar compamies. ${ }^{163}$

159. Id. at 1162. For a summary of the legislation and dates of enactment, see the chart provided, id. at 1165 .

160. Id. at 1162 .

161. For a detailed account of railway companies' continued resistance to segregation ordinances, see Roback, Segregated Streetcars, supra note 156, at 899-916.

162. Id. at 894.

163. Roback, supra note 157 , at 674 . 
What Roback's analysis suggests is that legislation subordinating people of color arose not to reinforce a inarket-generated hierarchy, but to redress the market's perceived failure to provide the "public good" of such a hierarchy. Indeed, she concludes her examination of Jim Crow legislation by observing,

There is hardly any question that legal sanctions were necessary to enforce discrimination against blacks. After all, if social pressure, economic power, and custom were sufficient, why did Southern whites bother to enact labor laws in order to extract what was wanted from blacks? ... In any case, the evidence indicates that the law, not the narket, was the chief oppressor of blacks in the Jim Crow period. ${ }^{164}$

If Roback is correct, then the Crits' assumption that markets are inherently racially subordinating is wrong. ${ }^{165}$

This, of course, does not represent the only way in which the pragmatic orientation of public choice theory might undermine some of the Crits' proposals. Additional doubts might be raised by the scholars studying the theory of bureaucracy who would remind us that proposals for political action must be judged not as ideal formulations, but as measures to be instituted by the ordinary human beings who work for the government. ${ }^{166}$ They would contend that since it is the decisions of the officials charged with putting the law into effect that will determine what it accomplishes, one can never safely assume that any legal provision will serve the ends intended by its authors. ${ }^{167}$ This is not because there is anything inherently corrupt or inefficient about people who work for the government. Indeed, it is when political functionaries are devoted to their jobs that the law as applied is most likely to

164. Roback, Jim Crow, supra note 156, at 1191-92.

165. See David E. Bernstein, Roots of the 'Underclass': The Decline of Laissez-Faire Jurisprudence and the Rise of Racist Labor Legislation, 43 AM. U. L. REV. 85 (1993) (arguing that the liberty of contract, not labor legislation, served to protect the interests of disenfranclised workers during the Lochner era).

166. See sources cited supra note 142.

167.

Bureaucratic decision-makers are human beings. This simple fact is only now beginning to be acknowledged in the theories of bureaucracy. The individual who is confronted with a choice among alternatives must clioose, and the cost that inhibits decision is his own evaluation of the alternative that inust be foregone.

JAMES M. BUCHANAN, COST AND CHOICE: AN INQUIRY IN ECONOMIC THEORY 98 (1969). 
diverge froin the intent of the law as written. As the public choice theorists point out when discussing the actions of government officials,

As a rough rule of thumb, those people who do work hard and prepare themselves well are those people who have their own idea of what government should do in their particular division and work hard at that.... [T] hey are usually well-intentioned individuals who can be criticized only in that their idea of the public good may or may not coincide with that of their superiors. If it does not comcide, this does not prove that they are wrong and the superiors right, but it does mean that the government is not apt to follow a coordinated policy. ${ }^{168}$

Thus, the public choice scholars would remind us that the desirability of any proposed legal provision must be evaluated on the basis of the effects it is likely to have as implemented rather than those that its proponents intend.

As illustration, consider again the Crits' argument for the legal empowerment of women and people of color. Another assumption upon which this argument rests is that the pohtical apparatus of society can, in fact, be used to effectively empower currently subordinated groups. The public choice scholars would insist that whether this is true or not depends on the nature of the apparatus to be employed. For example, one proposed method to combat the subordimation of women is the passage of Catharine MacKinnon and Andrea Dworkm's anti-pornography statute, which would allow the enjoinment of the production, sale, exhibition, and distribution of pornography that "consists of 'the graphic sexually exphicit subordination of women through pictures or words'... [and] portray[s] women in sexually degrading contexts, mcluding submissive or servile poses, or sexualized in a manner involving violence."169 In Butler v. Her Majesty the Queen, ${ }^{170}$ the Canadian

168. Tullock, supra note 139 , at 1043.

169. Note, Pornography, Equality, and a Discrimination-Free Workplace: A Comparative Perspective, 106 HARV. L. REv. 1075, 1076 (1993) (citations omitted). The statute referred to is the civil rights statute written by Catharine MacKinnon and Andrea Dworkin which defines pornography as illegal sex discrimination and which has been proposed for adoption in several states and municipalities. See id. at 1075 n.1. For the full text of the statute as well as an explicit statement of its rationale as a means for the empowerment of women, see Andrea Dworkin, Against the Male Flood: Censorship, Pornography, and Equality, in FEMINIST JURISPRUDENCE 449 (Patricia Smith ed., 1993).

170. 1 S.C.R. 452 (Can. 1992). 
Supreme Court essentially engrafted this definition onto Canada's obscenity statute by reading the language that criminalizes the production and distribution of materials-" "a dominant characteristic of which is the undue exploitation of sex"171_to include "degrading or dehumanizing inaterials [that] place women (and sometimes men) in positions of subordination, servile submission or humiliation." ${ }^{172}$ However, because the agents charged with the enforcement of this statute apparently have a different interpretation of what is degrading, dehumanizing, and humiliating than either MacKinnon and Dworkm or the Justices of the Supreme Court of Canada, the Butler ruling has been einployed to justify the seizure of gay and lesbian literature as well as two of Dworkin's own books, while apparently reducing the pressure on traditional forms of pornography. ${ }^{173}$

Furthermore, even when the functionaries cliarged with a statute's implementation are completely sympathetic to its intended ends, public choice theorists would point out that the functionaries' individual career goals, budgetary concerns, and personal agendas virtually guarantee that its enforcement will give rise to a myriad of unintended consequences. ${ }^{174}$ For example, the Equal Employment Opportumity Commission and the Justice Department's Civil Rights Division are clearly composed of people dedicated to the intended goal of Title VII of the Civil Rights Act which, as stated by Hubert Humphrey, one of its principal sponsors, is to relieve

171. Criminal Code, R.S.C., ch. C-46, $\S \S 163(1), 163(8)$ (Can. 1985).

172. Butler, 1 S.C.R. at 479 . The Court clearly showed that it was adopting the essence of the MacKinnon/Dworkin theory of pornography as sex discrimination:

[I]f true equality betweeu male and feinale persons is to be achieved, we cannot ignore the threat to equality resulting from exposure to audiences of certain types of violent and degrading material. Materials portraying women as a class as objects for sexual exploitation and abuse lave a negative impact on "the individual's sense of self-worth and acceptance."

Id. at 497 (quoting R. v. Red Hot Video Ltd., 45 C.R.3d 36, 43-44 (B.C.C.A. 1985)).

173. See Sarah Lyall, Canada's Morals Police: Serious Books at Risk?, N.Y. Times, Dec. 13, 1993, at A8; Mary Williams Walsh, Chill Hits Canada's Porn Law, L.A. TIMES, Sept. 6, 1993, at A1. The two books that were seized, ANDREA DWORKIN, PORNOGRAPHY: MEN POSSESSING WOMEN (1989) and ANDREA DWORKIN, WOMEN HATING (1974), were confiscated because they "iilegally eroticized pain and bondage." Walsh, supra at A17. The L.A. TIMES article also contains an illuminating quote from Kimberly Mistyshyn, the manager of the Glad Day gay bookstore, on the distinction between the law as written and the law as applied. She states, "It's really sad that the Butler decision, which was supposed to be positive for women, has deeply affected the lesbian commmity. The lesbian commumity [consists of] women." Id.

174. Tullock, supra note 139, at 1042-43. 
"the plight of the Negro in our economy" and "open employment opportunities for Negroes in occupations which have been traditionally closed to them."175 Yet, these agencies have interpreted the requirements of Title VII to create a set of financial imcentives such that "when deciding where to locate a new plant or wliere to expand an existing one, a firm will be attracted (other things being equal) to areas that have only small percentages of blacks in their labor pools." 176 Public choice scholars would insist that considerations such as these have a direct bearing on whetler antidiscrimination statutes should, in fact, be extended into the private realm $^{177}$ and how likely large-scale affirmative action programs are to accomplish their goals. ${ }^{178}$

These examples in no way show that the Crits' proposals to legally empower subordmated groups will not, in the long run, prove to be the most effective means to eliminate racial and sexual subordmation. What they do show, however, is that if the Crits are truly interested in ending subordmation, then they must take the time to explore both the extent to which market forces, rather

175. 110 CONG. REC. 6548 (1964).

176. Richard A. Posner, The Efficiency and Efficacy of Title VII, 136 U. PA. L. REv. 513,519 (1987). This effect is due primarily to the disparate impact approach to proving discrimination. Disparate impact is usually determined by comparing the percentage of minorities in the workforce with the percentage in the qualified local labor pool. However, since it is extremely expensive both to keep the records required to prove the absence of disparate impact and, if there is a disparate impact, to prove that the hiring methods employed meet the standard of business necessity, companies have a strong incentive to avoid these costs by locating away from minority populations. This effect is also partially due to the added expense of hiring and discharging minority employees under the current interpretation of disparate treatment that "operate[s] as a tax on employing [minority] workers and give[s] firms an incentive to locate in areas with few [minorities]." Id; see also RICHARD A. EPSTEIN, FORBIDDEN GROUNDS 214-16, 262-63 (1992). Direct evidence of the effect of these incentives was presented in Terry Properties, Inc. v. Standard Oil Co. (Ind.), 799 F.2d 1523, 1527 (11th Cir. 1986) (involving defendant that wished to build its plant in a city with a minority population of $35 \%$ or less).

It is worth noting that the Crits recognize the distinction between the purported goals of the law and the ends it actually serves when implemented when they are criticizimg legal liberalism. For instance, in the context of the current example, the Crits contend that although liberal antidiscrimination legislation claims to establish equality for women and minorities, it actually serves to support the current racial and sexual hierarchy. See, e.g., Alan D. Freeman, Legitimizing Racial Discrimination Through Antidiscrimination Law: A Critical Review of Supreme Court Doctrine, 62 MINN. L. REv. 1049 (1978). In the present context, the public choice scholars may be viewed as pointing out that the same may well be true of the Crits' own proposals.

177. See supra note 78 and accompanying text.

178. See supra notes $80-81$ and accompanying text. 
than state action, are responsible for it and the degree to which the necessity of implementing any legal empowerment provision through the political process is likely to reduce its expected effectiveness. If, after such an investigation, the evidence indicates that the empowerment provision, as implemented, is likely to be superior to the unregulated market in eliminating the unwanted subordination, the Crits should continue to advocate its adoption. However, until such an exploration is undertaken, the Crits' proposals have nothing to recommend them over those of the classical liberals. ${ }^{179}$

Although the examples discussed so far have focused on the Crits' proposals to eliminate racial and sexual hierarchies, the hypothesized public choice critique of the Crit agenda would be perfectly general. Were they to address the Crits, the public choice scholars might point out that, regardless of the specifics, to propose that the commuinty act through the agency of the law is to propose an act of collective clioice. Their claim would simply be that no such proposal can be justified in the absence of a realistic comparison of both the benefits and the costs of collective action with those of individual action, i.e., of a pragmatic assessment of the relative strengths and weaknesses of political versus market action. ${ }^{180}$ The public choice rejoinder to the Crits' claim that the

179. Although my remarks in this section have been addressed only to the mainstream Crits, what I am characterizing as the public choice critique of Critical Legal Studies applies with equal force to the irrationalists. Recall that although the irrationahsts believe that legal judgments must be made intuitively, this does not imply that they are to be made randomly. See supra text accompanying notes 127-28. Indeed, since the conclusion the irrationalists draw from legal indeterminacy is that human beings are both empowered to make the decisions necessary to transform society and required to "accept personal responsibility for the part they play in the legal system and society at large," Fischl, supra note 12 , at 532, such judgments must not be made randomly. However, to transform society or to make responsible decisions one has to have some idea of what the consequences of one's decisions are likely to be. For this reason, the irrationalists are forced to recognize that legal judgments must be based not only upon reflection, emotion, and discussion, but also upon "predict[ions of] the most likely consequences of following different courses of action." Singer, supra note 83, at 65 . Thus, even the irrationalists would need to know whether a proposed legal intervention is more likely to bring about its intended end than no intervention at all in order to make a useful legal judgment. Hence, they, too, would seem to be obliged to make the type of comparative study the public choice scholars recommend.

180. In its simplest terms, the public choice scholars are calling for a fair basis of comparison. They are criticizing traditional economists and, by implication, the Crits for comparing the results of the actual, imperfect market with the ideally-functioning political system. They would contend that this is as aburd as comparing the economists' notion 
indeterminacy argument proves that law is politics would be that this is only half the story. They would claim that the recognition that law is politics carries with it an obligation to examine how the political process actually works. Thus, they would contend that the indeterminacy argument deinands precisely the type of pragmatic examination of pohitical forces in which they are engaged. And smce the Crits are apparently uninterested in participating in this examination, the public choice scholars could make a reasonable case that it is they, rather than the Crits, who are pursuing the line of analysis that the indeterminacy argument actually recominends.

\section{The Evidence of the Classical Liberals}

I have characterized the public choice scholars as pursuing the realists' project of pragmatic legal criticisin in a conteinporary setting. I have also suggested that they may be seen as admonishing the Crits that in the absence of empirical studies to determine whether the values they seek are more likely to be realized through the pohtical process than through the play of market forces, there is nothing to recommend the Crits' agenda over that of the classical liberals. At this point, a classical liberal might suggest that, to the contrary, there is inuch to recommend the classical hiberal agenda over that of the Crits. The classical liberal might point out that there is really nothing new about the type of research called for by the realists and undertaken by the public choice scholars. He might point out that looking through the forms of the law to its actual effects on the human condition and criticizing pohtical action for failing to recognize its empirical limitations has long been at the heart of the classical liberal project. He might remind us that well before the advent of the "public choice" label, classical hiberal economists such as Adam Smith, Ludwig von Mises, and F.A. Hayek were attacking legal provisions not because the ends that they were intended to achieve were morally objectionable, but because of the empirical impossibility of achieving those ends via the political apparatus. Finally, the classical liberal

of the perfectly competitive market with the results of the real-world political process complete with compromises, corruption, and ideological struggle. The public choice scholars are claiming that what is needed is a comparison of like with like, i.e., of the results that can be obtained through the imperfect, real-world market with those that can be obtained through the imperfect, real-world political process. 
might suggest that the research of these forerunners of public choice theory indicates that, in many cases, the Crits' are less likely to achieve their desired ends through the political action they advocate than they would be by allowing individuals to act freely. ${ }^{181}$

Consider, for example, the work of Ludwig von Mises. As early as 1920 , he was criticizing socialist proposals to employ the machinery of the state to increase social welfare and create a inore egahtarian society because, however desirable these goals may be, the inability to engage in economic calculation in the absence of private ownership of the ineans of production made their achievement impossible by the means advocated. ${ }^{182}$ After

181. A distinction is necessary at this point. The Crits almost invariably identify classical liberals with the adherents of eighteenth-century style natural rights theory who believe that human personahity springs to life de novo independent of social influences. Thus, Mark Kelman characterizes classical liberalism as follows:

Libertarians start with the supposition that individuals possess certain natural rights, which the state is created simply to protect. Collective bodies . .. simply ratify a natural, conceptually preexisting scheme of entitlements. The scheme of entitlements that is ostensibly simply "recognized" is supposedly the only one compatible with the observation that persons are fundamentally separate, . . . . [Libertarians] do indeed posit that we can imagine some set of authentic individual desires antedating and independent of the existence of a community.

Mark Kelman, A Critique of Conservative Legal Thought, in THE PoLITICs OF LAw, supra note 9 , at $436,437-38$.

Now, it is certainly true that eighteenth century thinkers such as Locke, Hutcheson, and Blackstone behieved in natural rights, see WILLIAM BLACKSTONE, COMMENTARIES ON THE LAWS OF ENGLAND 68-69 (B. Gavit rev. ed., 1941) (1765); JOHN LOCKE, SECOND TREATISE OF GOVERNMENT § 95 (C.B. MacPherson ed., 1980) (1690); Francis Hutcheson, A Short Introduction to Moral Philosophy, in 4 COLLECTED WORKS 141-43 (1969) (1747), although it is extrenely doubtful that they subscribed to the atomistic view of human beings that Kelman and others attribute to thein. See STEPHEN HOLMES, THE ANATOMY OF ANTILIBERALISM 190-97 (1993). However, finding contemporary, or even modern, classical liberal theorists who fit Kelman's description is at least as difficult as finding an actual legal formalist. Robert Nozick appears to be the usual suspect, although it is arguable whether even he fits this description. See NozICK, supra note 58. If there are other contemporary political theorists who present the naive arguments the Crits ascribe to classical hiberals, I am unable to locate them. For two good examples of contemporary classical hberal theorists who definitely do not fit the mold the Crits have formed for thein, see LOMASKY, supra note 58 and RASMUSSEN \& DEN UYL, supra note 58.

Assuming, however, that there are classical hiberals who base their arguments on natural rights and the belief that individual choice is not affected by social circumstance, these are not the theorists I am referring to in the present context. Rather, I am addressing the classical hiberals whose arguments concern the practical limitations of governmental action. Such theorists are usually, but not exclusively, econoinists. As is the case with the other groupings of theorists discussed in this article, it is best to read my comments about the classical hberals as applying only to those I actually cite.

182. See Ludwig von Mises, Die Wirtschaftsreuuchnung im sozialistischen Gemeinwesen, 
being virtually ignored for fifty years, many economists now believe that this "economic calculation argument" was proven correct by the failure of the Soviet Umion; ${ }^{183}$. Robert Heilbroner, going so far as to assert, "It turns out, of course, that Mises was right." ${ }^{184}$ If this is indeed the case, it must have serious implications for the feasibility of any of the Crits' proposals that require democratic or political control of the means of production. ${ }^{185}$

Similarly, in the 1940s, F.A. Hayek attempted to demonstrate that the inherent shortcomings in the knowledge-gathering abilities of human beings limited what could be effectively achieved

47 ARCHIV FUR SOZIALWISSENSCHAFTEN UND SOZIALPOLITIK 86-88 (1920).

183. See DAvid RAMSAY STEEL, FROM MARX to MISES 3 (1992). This book provides a thorough discussion of the economic calculation argument and its practical significance for economic reforms intended to produce a more egalitarian society.

184. Robert Heilbroner, After Communism, THE NEW YORKER, Sept. 10, 1990, at 92.

185. It is interesting to note the remarkable extent to which Mises' work reads like a template for later public choice theory. An early analog of Jennifer Roback's demonstration that the market was not responsible for the subordination of people of color can be found in his book Socialism, which was first published in 1922. In this book, Mises examined the condition of women under capitalism in order to show that not only were narket forces not responsible for their subordination, but that it was the liberal notion of women as parties to a marriage contract that elevated them froin their status as chattel in the pre-capitalistic era to that of autonomous parties able to enter into reciprocal arrangements with men. See LUDWIG VON MISES, SOCIALISM 83-87 (Liberty Classics 2d ed. 1981) (1922). Furthermore, one can find an early version of the arguments made by the public choice theorists working on the theory of bureaucracy in his 1944 book, Bureaucracy. In this book, he explained that because public officials have no price structure to inform them when the further pursuit of their department's goals would use up public resources that would be better spent on other important social problems, it is prccisely the honest and efficient public manager who is most likely to produce untoward consequences not intended by those who write the laws. See LUDWIG VON MISES, BUREAUCRACY 59-63 (1944).

Indeed, it is easy to find in Mises' early work both the criticism of abstract reasoning without empirical analysis and the call for a realistic basis of comparison between market and polifical forces that would subsequently be echoed by both the realists and the public choice scholars. The first is evident in his criticism of the social philosophers of his day on the grounds that "[ $t]$ lhey see people poor and in want, but do not try to discover whether this is due to the institution of private property or to attempts to restrict it. . . They judge, without first having made themselves familiar with the rcsults of econonnic science." vON MISES, SOCIALSIM, supra at 389. The second is exemplified in his comparison of socialism and liberalism:

Socialism sees the individuals-the leungry, the unemployed, and the rich-and finds fault on that acconnt; Liberalism ... knows well enough that private ownership in the means of production is not able to transform the world into a paradise; it has never tried to establish anything beyond the simple fact that the socialist order of society is unrealizable, and therefore less able than Capitalism to promote the well-being of all.

Id. at 461. 
through centralized, collective action. ${ }^{186}$ Hayek showed how market price structures serve as "a system of telecommunications"187 by which large numbers of people could transmit and receive the information necessary to coordinate their actions. He argued that to reform any aspect of the economy politically, the reformers would have to find a substitute for the information-generating function of the market; they would have to find a way of amassing the knowledge of economic conditions necessary to institute their reforms intelligently. This, according to Hayek, was not merely practically difficult, but was theoretically impossible because so much of the requisite knowledge was inherently local in nature, consisting in the specialized knowledge of individuals at specific times and places that could never be effectively centralized. For this reason, all such reform efforts would be beset by a certaim amount of ineradicable uncertainty that would often produce unintended consequences quite at odds with the ends the reformers wished to achieve. ${ }^{188}$ If correct, this observation must cast significant doubt upon the efficacy of Crit proposals to place an everexpanding percentage of society's economic operations under dernocratic or communal control. ${ }^{189}$

186. See Friedrich A. HAYEK, THE RoAd to SERFDOM 48-50 (1944).

187. FRIEDRICH A. HAYEK, INDIVIDUALISM AND ECONOMIC ORDER 87 (1948).

188. This, of course, represents only a cursory and highly incoinplete account of Hayek's treatment of the "knowledge problem." For a fuller discussion, see generally HAYEK, supra note 187. A useful compilation of Hayek's thinking on this subject is FRIEDRICH A. HAYEK, ORDER: WITH OR WITHOUT DESIGN (Naomi Moldofsky ed., 1989). See also FRIEDRICH A. HAYEK, KNOWLEDGE, EVOLUTION, AND SOCIETY (1983).

189. It is important to note that Hayek was always at great pains to point out that his arguments concerned empirical matters of fact, not disagreements over values. In fact, he explicitly admitted to sharing "some values widely held by sociahists." FRIEDRICH A. HAYEK, THE Fatal Conceit: THE ERrors of Socialism 8 (1988). Like the later public choice theorists, he was concerned with the pragmatic analysis of what conld be achieved by private and collective action respectively. Thus, he states,

The mam point of my argument is, then, that the conflict between, on the one hand, advocates of the spontaneous extended human order created by a competitive market, and on the other hand those who demand a deliberate arrangement of human interaction by central authority based on collective colnmand over available resources is due to a factual error by the latter about how knowledge of these resources is and can be generated and utilised. . .

This is why, contrary to what is often maintained, these matters are not merely ones of differing interests or value judgements.

Id. at 7. Interestingly enough, Hayek's criticism of the type of collective action generally advocated by the Crits employs precisely the same critical technique that the Crits employ against hberalism, the immanent critique. This is illustrated by his comments on the morality underlying collective action: 
As a final example, consider the work of Adam Smith, whose The Wealth of Nations ${ }^{190}$ is essentially one long excursus on the empirical limitations of what may be accomplished through society's political machinery. In that work, Smith provides one of the earliest as well as one of the best illustrations of the difference between the law-in-books and the law-in-action in his examination of England's poor laws. ${ }^{191}$ There, Smith explained how seventeenth century laws designed to provide support for the indigent actually served to depress the wages of the working poor for over a century. When the charity that had formerly supported the poor disappeared with the inonasteries, the Crown had required "that every parish should be bound to provide for its own poor; and that overseers of the poor should be annually appointed, who, with the church-wardens, should raise, by a parish rate, competent sums for this purpose."192 Smith observed that this statute gave each parish a strong incentive to ensure that no outsider who was impoverished or presented the risk of becoming so could settle within it because this would add to the community's burden. But since the working poor always presented such a risk, the statute almost completely destroyed the mobility of labor. As Smith writes,

No independent workman, it is evident, whether labourer or artificer, is likely to gain any new settlement either by apprenticeship or by service. When such a person, therefore, carried his industry to a new parish, he was liable to be removed, how healthy and industrious soever, at the caprice of any churchwarden or overseer, unless he either rented a tenement of ten pounds a year, a thing inpossible for one who has nothing but his labor to live by; or could give ... a security [of at least thirty pounds] which scarce any man who lives by his labour can give. ${ }^{193}$

As a result, workmg men were prevented from improving their standard of living by inoving to those areas of the country in

If such a morality pretends to be able to do something that it cannot possibly do, e.g., to fulfill a knowledge-generating and organisational function that is impossible under its own rules and norms, then this impossibility itself provides a decisive rational criticism of that moral system.

Id. at 8 .

190. ADAM SMITH, THE WEALTH OF NATIONS (Edwin Cannan ed., 1937) (1776).

191. Id. at 135-41.

192. Id. at 136 (citing 43 Eliz., c.2).

193. Id. at 138 . 
which their labor was more highly valued and could bring higher wages:

The very unequal price of labor which we frequently find in England in places at no great distance from one another, is probably owing to the obstruction which the law of settlements gives to a poor man who would carry his industry froin one parish to another without a certificate. ${ }^{194}$

Thus, by precisely the type of analysis that public choice scholars practice today, Smith demonstrated how a law designed to aid the poor produced a situation such that, "[t]here is scarce a poor man in England of forty years of age ... who has not in some part of his life felt himself most cruelly oppressed by this illcontrived law of settlements." 195

On the basis of evidence such as this, a classical hiberal could contend that there are significant empirical limitations on what can be accomplished through centrally-guided, democratic collective action. If so, he would probably argue that the Crits' demonstration that the mdeterminacy argument shows that law is indistinguishable from politics does not miply support for a program of radical political action designed to restructure society along more

194. Id. at 140. The certificate referred to is a device that was subsequently introduced for the specific purpose of rectifying the restriction of labor mobility that had been produced by the law of settlements. However, as Smith points out, this remedial statute itself had the contrary effect of "imprison[ing] a man as it were for life; however inconvenient it may be for him to continue at that place where he has had the misfortune to acquire what is called a settlement, or whatever advantage he may propose to himself by living elsewhere." Id. (quoting RICHARD BURN, HISTORY OF THE POOR LAWS 235-36 (1764)). For the full discussion, see id. at 138-40.

195. Id. at 141. I might point out that if it is reasonable to regard Smith as a forerunner of public choice theory, then he probably should be considered the first legal realist as well. For, rather than taking judicial reasoning at face value in his study of the Enghish legal system, he noted that as long as the dispensation of justice remained a source of revenue to the state, the reality of judicial procedure was such that

[t]he person, who applied for justice with a large present in his hand, was likely to get something more than justice; while he, who applied for it with a small one, was likely to get something less. ... [and t]he amercement, besides, of the person coinplained of, might frequently suggest a very strong reason for finding him in the wrong, even when he lad uot really been so.

Id. at 675 . Indeed, if I were to stretch things a bit, I might even suggest that there is a sense in which Smith was the first Crit as well since he took the time to point out that "[w]hen the judicial is united to the executive power, it is scarce possible that justice should not frequently be sacrificed to, what is vulgarly called, politics." Id. at 681 . 
"humane," "egalitarian," "democratic," or "nonhierarchical" lines. ${ }^{196}$

Rather, the classical liberal would contend that the most this observation can imply is that such action should be undertaken in those cases in which it is empirically possible for collective political action to help achieve this end. But the classical hberal can claim that, unlike the Crits, he is able to call upon a long line of einpirical research to demonstrate that, in a great many cases, collective political action cannot create such a society more effectively than can politically unrestrained individuals functioning im a market environinent. Thus, he could reasonably contend that the indeterminacy argument lends at least as much support to the classical hiberal agenda as it does to the critical one.

\section{CONCLUSION}

In this article, I have examined the implications that can be drawn from the assumption that the law is indetermmate. The Crits have argued that legal indeterminacy imphes that there is no distinction between law and politics. They have concluded from this that the law should be employed as a weapon in the pohtical struggle to destroy the illegitinate hierarchies of liberalism and produce a more egahtarian and democratic society. To this end, they have advanced many novel proposals for the legal regulation of human conduct.

I have suggested that this greatly overstates what the indeterminacy argument actually imphes. Rather, the proper inference to draw from a demonstration that the law is indistinguishable from politics is that the cases in which the law should be employed to reform society are limited to those in which the desired reforms can be effectively realized through political action. The insight the legal realists provided long ago was that to identify these cases, one must undertake the pragmatic examination of how the law works in practice relative to alternative methods of social control. Thus, there is a need for empirical investigation to determine how the expected outcomes of collective political action compare with those of pohtically unrestramed individuals functioning in a market environment. Further, to be vahd, this imvestigation must compare like with like; it nust compare what can reasonably be achieved

196. See supra text accompanying notes 66-69. 
through real-world pohitical processes staffed by less than perfect human beings with what is likely to result from unrestrained human interaction in the flawed markets that actually exist, not the utopian results of an ideal political system with those of imperfect, real-world markets. Because this is the case and because the Crits have resisted undertaking such investigations, I have argued that they have missed the point of the indeterminacy argument, and that if this argument is in fact correct, the way forward into our jurisprudential future lies in a return to the uncoinpleted project of the realists.

I have furtlier argued that because it is the public choice scholars who are presently at work on this project, it is they, rather than the Crits, who are pursuing the line of inquiry the indeterminacy argument actually recommends. Further, to the extent that they, like the classical hberal economists who preceded them, identify the limits of practicable collective action, they cast considerable doubt on the proposals of the Crits that transgress these limits. For this reason, I have suggested that if, indeed, there are many cases in which the empirical evidence suggests that the values the Crits support would be better served by removing pohitical constraints entirely rather than instituting measures of direct political control, the indeterminacy argument would seem to support the classical hiberals' agenda as much as that of the Crits.

It may be true that by demonstrating that the law is indeterminate the Crits have shown that law is politics. It may also be true that they have shown that the law reflects the ideology of pohitically dominant groups and thus oppresses politically subordinated groups. But it is not true that they have shown that the most effective way to remedy this oppression is to enlist the coercive apparatus of the state. Indeed, if the public choice scholars and classical hiberals are correct in asserting that market forces are frequently more effective at combatting this oppression than is political action, the imphication of the indeterminacy argument may well be not that we inust engage in a pohtical power struggle for the control of the state in order to coercively impose the proper non-hierarchical or egalitarian or democratic values on society, but rather that we inust greatly curtail the state's coercive activities if 
these values are to flourish. In 1815, Benjamin Constant suggested that in their commitment to democratic egalitarianism the Jacobin followers of Jean-Jacques Rousseau

saw in history a small number of men, or even a single man, in possession of an immense power, which did much harm, but their wrath was directed against the possessors of power, and not against the power itself. Instead of destroying it, they only dreamt of displacing it. It was a scourge, and they regarded it as a conquest. ${ }^{197}$

In this article, I have suggested that this comment may well be equally applicable to the Crits.

197. See Ralph Raico, Benjamin Constant, 3 NEW INDUSTRIALIST REV. 45,49 (1984). 